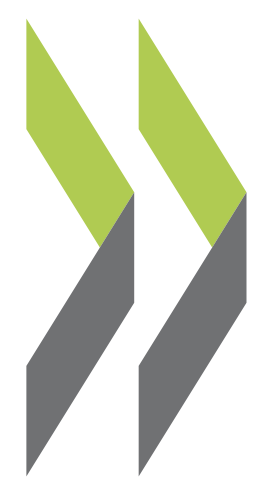

OECD Science, Technology and Industry Working Papers 1999/02

\title{
The Globalisation of Industry in the OECD Countries
} Thomas Hatzichronoglou 


\section{Unclassified}

OECD III $\overline{\text { OCDE }}$

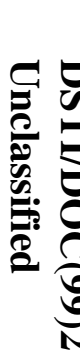

Organisation de Coopération et de Développement Economiques

Organisation for Economic Co-operation and Development

DIRECTORATE FOR SCIENCE, TECHNOLOGY AND INDUSTRY

OLIS : 20-Sep-1999

Dist. : 22-Sep-1999

DSTI/DOC(99)2

STI WORKING PAPERS

1999/2

THE GLOBALISATION OF INDUSTRY IN THE OECD COUNTRIES

Thomas Hatzichronoglou 


\section{STI Working Paper Series}

The Working Papers series of the OECD Directorate for Science, Technology and Industry of the OECD is designed to make available to a wider readership selected studies prepared by staff in the Directorate or by outside consultants working on OECD projects. The papers included in the series are of a technical and analytical nature and deal with issues of data, methodology and empirical analysis in the areas of work of DSTI. The Working Papers are generally available only in their original language - English or French with a summary in the other.

Comment on the papers is invited, and should be sent to the Directorate for Science, Technology and Industry, OECD, 2 rue André Pascal, 75775 Paris Cedex 16, France.

The opinions expressed in these papers are the sole responsibility of the author(s) and do not necessarily reflect those of the OECD or of the governments of its Member countries.

Copyright OECD, 1999

Applications for permission to reproduce or translate all or part of this material should be made to: Head of Publication Service, OECD, 2 rue André-Pascal, 75775 Paris, Cedex 16, France. 


\section{THE GLOBALISATION OF INDUSTRY IN OECD COUNTRIES}

The most highly internationalised industries are thought to be more competitive than the rest, since their high exposure to international competition forces them to strive constantly to become more efficient and they are in a position to take advantage of all the opportunities that arise in world markets. But to determine whether this is in fact the case, each country's industries must first be classified in terms of their degree of globalisation.

This report proposes a method for classifying each country's manufacturing industries by their extent of globalisation, using a set of indicators. The results obtained show that the degree of globalisation is more closely linked to the characteristics of industrial sectors than to the country's specialisation. These results could be improved significantly if some of the proposed indicators were available.

\section{LA MONDIALISATION DES INDUSTRIES DANS LES PAYS DE L'OCDE}

Les industries les plus internationalisées sont considérées comme plus performantes que les autres à cause de l'effort permanent d'efficacité que nécessite leur forte exposition à la concurrence internationale et leur capacité à saisir toutes les opportunités qui se présentent sur les marchés mondiaux. La vérification empirique d'une telle proposition exige un classement préalable des différentes industries de chaque pays en fonction de leur degré de mondialisation.

Le présente rapport propose une méthode qui permet de classer les industries manufacturières de chaque pays selon leur degré de mondialisation, à l'aide d'un ensemble d'indicateurs. Les résultats obtenus montrent que le degré de mondialisation des différentes industries dépend davantage des caractéristiques des secteurs industriels plutôt que de la spécialisation de chaque pays. Ces résultats pourraient être sensiblement améliorés si certains indicateurs proposés étaient disponibles. 


\section{TABLE OF CONTENTS}

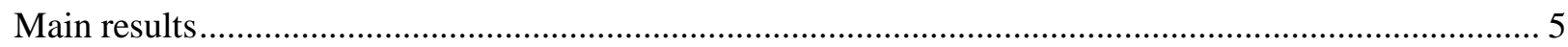

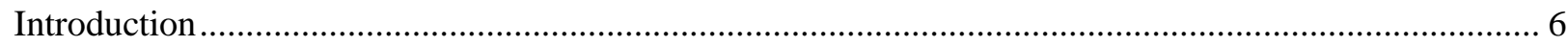

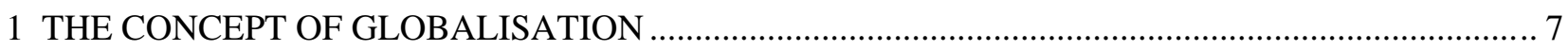

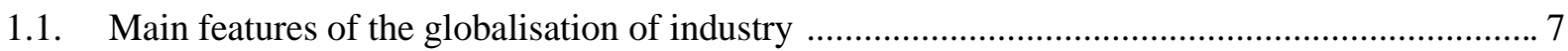

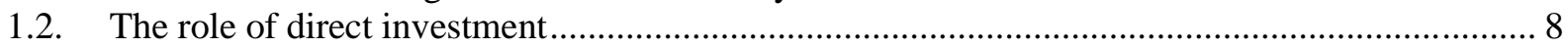

2. FROM CORPORATE TO SECTOR GLOBALISATION ..................................................... 11

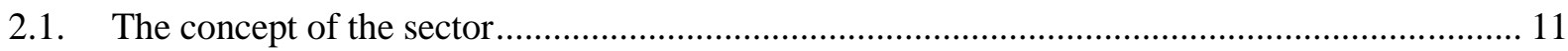

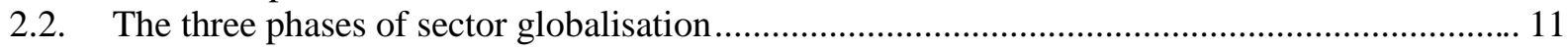

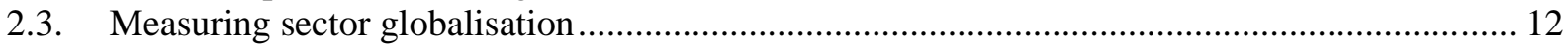

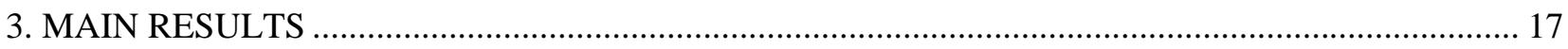

3.1. Internationalisation of the whole of manufacturing industry in the OECD countries ............. 17

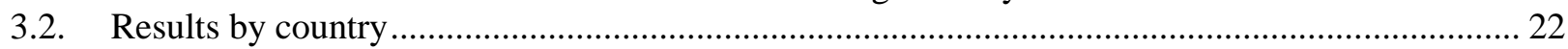

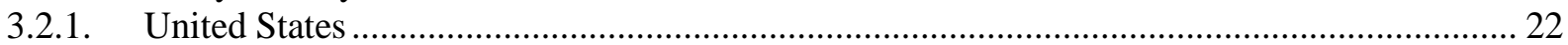

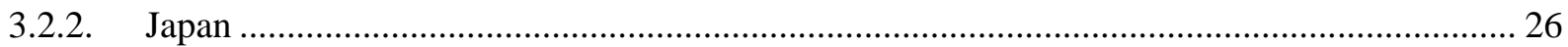

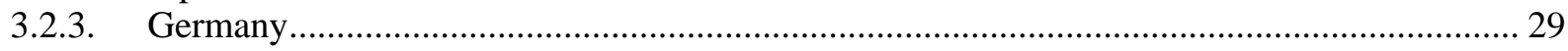

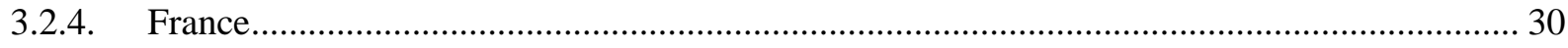

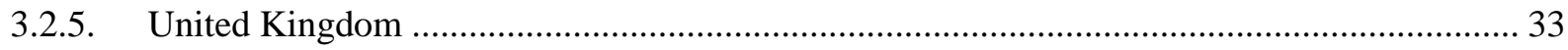

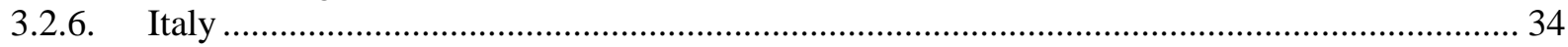

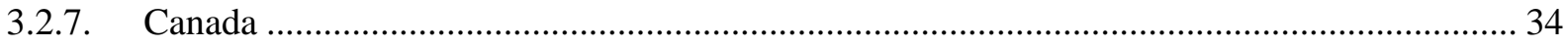

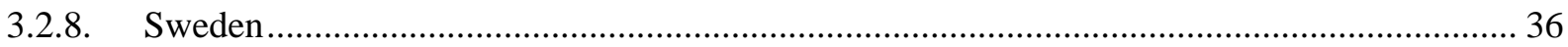

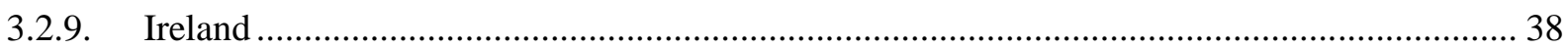

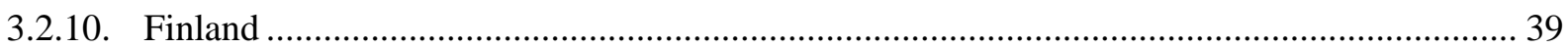

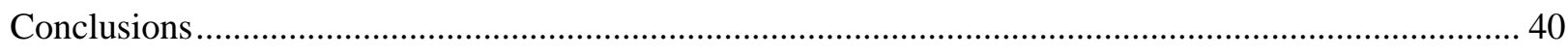

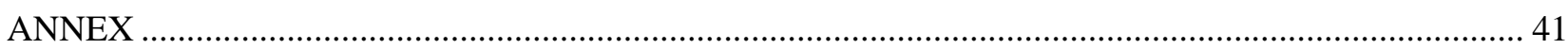




\section{Main results}

- Globalisation takes internationalisation a stage further, and is also more complex. Some of the aspects of globalisation concerning firms and industrial sectors are reiterated in Chapter 1 of this report.

- In adapting the analysis to data availability, the globalisation of industrial activity is a process that may be split historically into three phases which, at present, coexist: $i$ ) trade and, especially, exports; ii) production moved offshore by means of direct investment; and iii) the globalisation of technological innovation through the multiplication of R\&D centres abroad.

- The degree of globalisation of the different sectors of industry in each country was measured by means of sets of indicators characterising each of the above three phases, on both domestic and foreign markets.

- A combination of several indicators shows that industry in small countries is much more globalised than that of larger countries, but also that there are major disparities between countries of the same size. These could be attributable to differences in industrial development and also to the presence of multinational firms that originated in the said countries (e.g. the Netherlands, Switzerland, Sweden).

- Taking account of the geographical concentration of trade and direct investment reduces the degree of globalisation when trade and direct investment very largely stem from (or are aimed at) a single country (e.g. the United States in the case of Canada).

- Among the major (G7) countries, UK industry is the most globalised on both the domestic and foreign markets. Although American multinationals are much more numerous and are often much bigger, their weight in American industry as a whole is lower than those of many small economies.

- The most globalised manufacturing sectors are the high-technology and medium-high-technology sectors: computers, scientific instruments, pharmaceuticals, electronics, basic chemicals, electrical machinery and motor vehicles. The high degree of geographical concentration noted in the aerospace industry, coupled with the fact that it is highly export-oriented and not at all extensively established in foreign countries (highly limited direct investment) are such that it cannot be ranked among the most globalised sectors. Its classification might be different if other indicators currently not available were to be taken into account, notably the co-operation agreements and international subcontracting that are typical of this industry whose products rank among the most globalised in the world.

- The degree of globalisation of industry depends more on the characteristics of individual sectors than on each county's specialisation.

- Among the low-technology sectors, the most globalised industry is textiles and clothing. 
DSTI/DOC(99)2

\section{Introduction}

The liberalisation of trade and investment is providing new opportunities for firms which, by globalising their activities, are able to take more direct advantage of markets which are expanding or have appreciable technological potential.

The benefits that firms can derive from globalisation have been demonstrated in numerous theoretical and empirical studies. ${ }^{1}$ Firms which export ${ }^{2}$ and which invest abroad or are affiliates of foreign firms ${ }^{3}$ have higher and faster growing labour productivity, create more jobs, pay their employees higher salaries and generally expand more rapidly than comparable firms which export or invest abroad to a lesser extent. Also, because of their size and the fact that they are located in a number of countries, such firms have easier and lower-cost access to raw materials, technology and the most varied goods and services, all of which enables them to achieve appreciable economies of scale.

Their competitiveness is also enhanced by a substantial R\&D effort, which they may accomplish on their own or in conjunction with other firms and which gives them considerable innovative capacity and technological ascendancy.

These results, which have been verified either for individual firms or for total manufacturing industry (by making a distinction between domestic and foreign firms), suggest that the positive linkages observed between firms' performances and their degree of globalisation might also be found in the case of each individual sector. To check this hypothesis will involve measuring the degree of globalisation of the various industrial sectors. This has not been done systematically before.

The purpose of this report is to provide an initial classification of overall manufacturing industry in the OECD countries and, above all, of each country's individual industries on the basis of their degree of globalisation. It will be apparent throughout this report that, in addition to certain theoretical and methodological difficulties, the main impediment to achieving the above objective is the shortage of appropriate data and their lack of comparability at both national and international levels. That being said, a considerable effort has been made in many countries, which is what has made this study possible, but many countries are still not in a position to provide the information that is essential to this exercise. This again points to the importance of each country collecting the quantitative and qualitative information needed to analyse globalisation. Understanding what the latter involves and assessing its impact on the economy as a whole means, first and foremost, having access to apposite data and internationally comparable indicators.

The present report is divided into three parts:

- The first deals briefly with the concept of globalisation, its main characteristics and the importance that direct investment has taken on since the mid-1980s.

- The second part recalls some of the problems posed by defining what constitutes a sector and proposes various indicators which reflect their degree of globalisation.

- The third describes the empirical results of: $i$ ) a country classification according to the globalisation of their manufacturing industry as a whole; and, ii) a classification of industrial sectors on both the foreign and domestic markets of each country. Using these findings, a number of more general conclusions are drawn concerning the globalisation of industrial sectors irrespective of the situation of each individual country.

A statistical annex concludes the report. 


\section{THE CONCEPT OF GLOBALISATION}

Whereas internationalisation may be said to have been a phenomenon of the 1950-60s and a large part of the 1970s, globalisation constitutes a further and extremely complex stage, corresponding to changes that took off in the 1980s.

During the latter period, two major changes created a new situation that pushed internationalisation into its globalisation phase; these were "deregulation" policies and the new role in economic activity played by "information and communication technologies". In reality, globalisation is seen more as a microeconomic phenomenon, driven by the strategies and behaviour of firms. It is thus the forces behind competitiveness and competition at world level -- between firms, and also between regions and countries -- which are central to the discussion.

Deregulation was particularly extensive in the financial sector, and some other service sectors such as air transport and telecommunications. Financial deregulation freed capital movements, which expanded on an exceptional scale in consequence, while the easing of competition laws made possible horizontal mergers which previously had not been authorised.

The widespread dissemination of new communication technologies liberalised and accelerated international transactions (cross-border movements of information and capital, data transmission and, more recently, electronic trading without the distribution stage and which encompasses goods and services). It also made possible, by permitting direct and ongoing access, automated worldwide management of the banking and financial system, transport, commercial transactions and personal communications. The acceleration of the flow of information also allowed firms to adopt more decentralised and more autonomous modes of organisation, but also made possible greater centralisation of certain strategic services.

Furthermore, the disappearance of the centrally planned economies of Eastern Europe accelerated the liberalisation process as the economies in question gradually became part of the world economy. In addition, a number of developing countries, mainly in Latin America and in South-East Asia, increasingly engaged in reform.

\subsection{Main features of the globalisation of industry ${ }^{4}$}

The principal characteristic of globalisation is the unprecedented increase in competition between firms in different markets, as a result of which a growing number of firms find themselves competing with other firms on their home market as well as in foreign markets.

A second feature of global competitiveness is the internationalisation of production. The various elements that enter into the manufacture of a product (capital, labour, technology, raw materials, intermediate goods, distribution) may come from many sources; countries and firms are now so interdependent, and the links between them so complex, that it is sometimes quite difficult to determine exactly where the various elements come from. ${ }^{5}$ 
A third feature has to do with the pattern of international trade. With numerous affiliates being set up abroad by domestic firms and in host countries by foreign parent companies, intra-firm trade has been encouraged, this being trade between firms belonging to the same group. A fourth feature is the growing interdependence between the various levels of globalisation, namely direct investment, trade, transfers of technology and capital transfers (Figure 1). Direct investment flows generate exports from the countries making the investment; these exports are accompanied by transfers of technology and know-how, and capital movements. ${ }^{6}$ Two other developments may also be identified. First, trade is no longer virtually the sole vehicle of globalisation, since direct investment, although quantitatively smaller, now has a major role. Second, the emergence of an intangible component, especially services, in international transactions is one of the salient developments of the past 15 .

The globalisation process is not, however, confined to the above characteristics, but is much more complex. Thus, firms which are tending to become global need to improve their profitability by externalising certain activities and having greater recourse than in the past to subcontracting and a variety of local and foreign partners. The result is an increasing number of firm networks, which relationship cannot be reduced to the traditional subcontracting arrangement. The need to develop their technological capacity is prompting firms either to acquire other, innovative firms, or to conclude co-operation agreements or alliances.

The growth of co-operation agreements, notably concerning $R \& D$, has given rise to flows of know-how between firms, even if this research often relates to programmes of a pre-competitive nature and is confined to members of the network.

\subsection{The role of direct investment}

Since the second half of the 1980s, foreign direct investment has been the most dynamic factor in the industrial restructuring that has taken place on a world scale. Between 1985 and 1990, direct investment by OECD countries increased twice as fast as trade in goods and services, and more than twice as fast as production (Figure 2). After falling in the early 1990s, flows of foreign investment from the OECD countries picked up again sharply and as of 1996 had exceeded the record level of the late-1980s.

These developments were accompanied by a polarisation of industrial and banking investments in the Triad, i.e. North America, the European Union and Japan, while direct investment flows to developing countries contracted sharply at least until 1990. In the early 1990s, however, there has been an increase in flows to developing countries, particularly South-East Asian countries and China.

In contrast, north-north direct investment increased, most of it directed to the United States. During the 1980s, for the first time in its history, the United States was simultaneously the largest outward investor and the leading host country for inward direct investment, although over the same period its relative share of total direct investment fell.

At the same time, the share of production under foreign control increased appreciably between 1984 and 1994 in the majority of OECD countries (Figure 3). At the end of this period in some countries (Canada and Ireland), it exceeded 50\% while in most of the others it was between 10 and $20 \%$ of total manufacturing industry. 
Figure 1. Interdependence of the various levels of globalisation

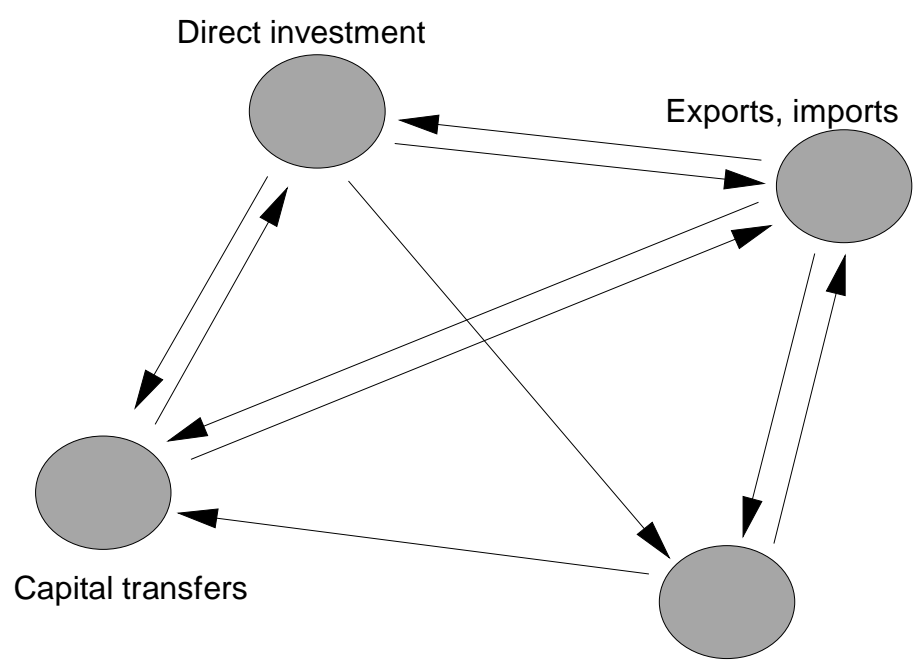

Technology transfers

Figure 2. Evolution of foreign direct investment ${ }^{1,3}$ of trade ${ }^{2,3}$, of GDP and of GFCF in the OECD area, in constant prices

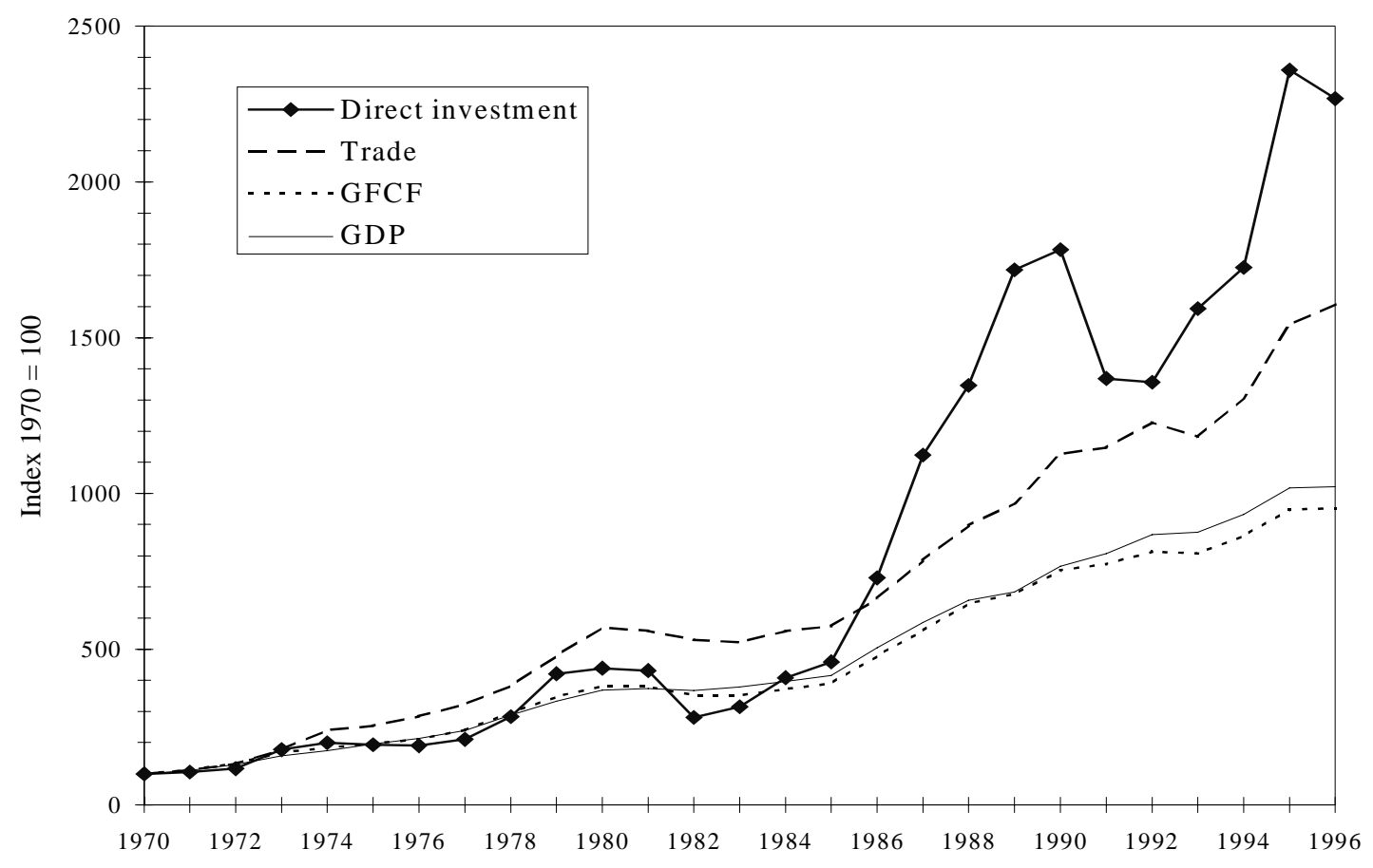

1. Average value of inward and outward investments.

2. Average value of imports and exports.

3. Including intra-OECD flows.

Source: OECD, DSTI/ EAS Division. 
Figure 3. Share of foreign affiliates' investment in manufacturing production, 1994 or nearest year

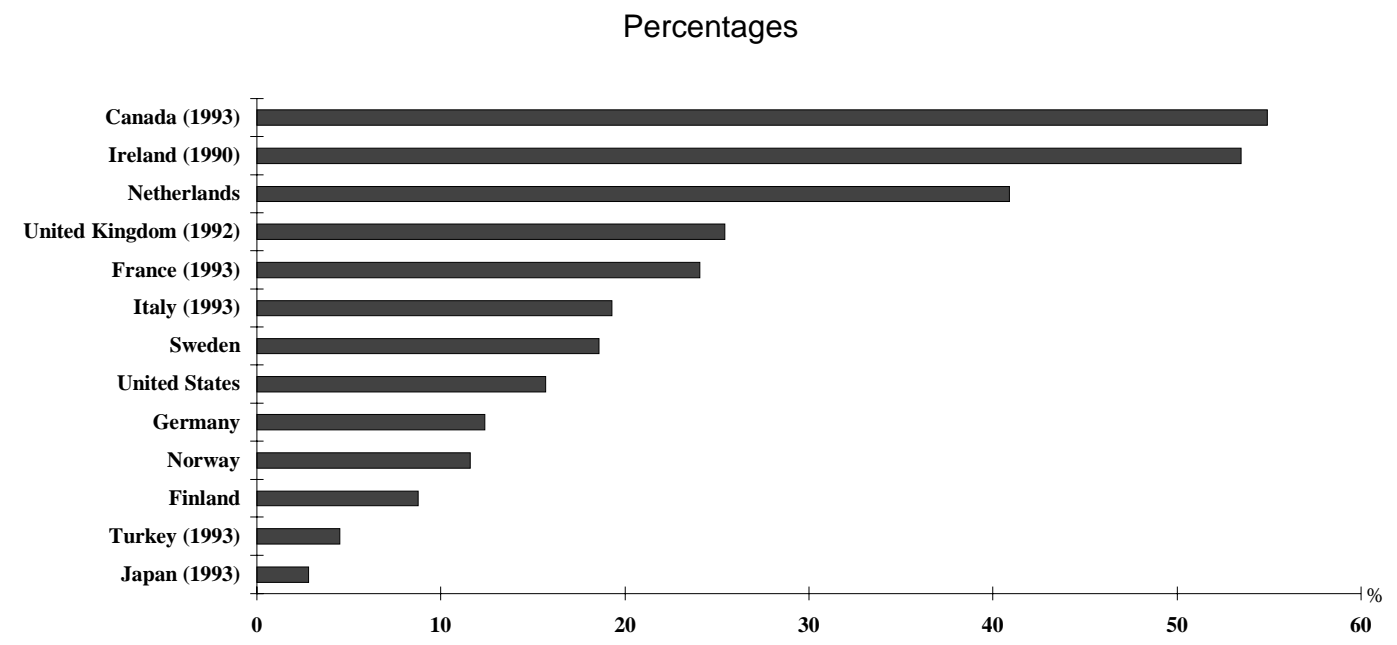

Source: OECD, AFA (DSTI/EAS Division). 
DSTI/DOC(99)2

\section{FROM CORPORATE TO SECTOR GLOBALISATION}

\subsection{The concept of the sector}

Although the aim here is to measure the degree of globalisation of the various sectors of industry, it will be useful to begin by restating the definition of a sector.

The term sector is usually given to a set of industrial or service activities that have characteristics in common. The criteria used to identify sectors (as defined in industrial classifications or in national accounts) vary widely, but the most common are the final use of the products manufactured (e.g. telecommunications, transport, etc.), the raw materials used (e.g. ferrous metals, paper, wood, etc.) and the technology (e.g. chemicals/pharmaceuticals, electronics).

According to national accounting definitions, a sector has a dominant activity (main activity) and a number of secondary activities which may or may not be related to the main one. Also very much part of the definition of a sector are the production units, of which there are at least three: the establishment, ${ }^{7}$ the firm (or company) ${ }^{8}$ and the group of companies. ${ }^{9}$

Whereas a large number of economic variables (production, employment, investment, value added, etc.) are collected at establishment level, other variables such as R\&D and data on affiliates are established and collected only at the level of the firm, which alone can pursue a policy of internationalisation. However, a firm can have a different main activity and hence belong to another sector. If the reference unit is the firm, comparisons will be more consistent for all the industrial variables, but the main drawback stems from the fact that, at the level of the firm, the main activity is of less significance than at establishment level.

It can happen that a firm's main activity, and more so still that of a group of enterprises -because of the greater diversification of their activities -- accounts for less than $10 \%$ of the turnover of the firm or group of firms. These considerations raise the question of choosing the appropriate level for the purpose of analysis. In this report, the basic unit selected is the enterprise, although the comparisons need improvements in the case of certain countries and variables.

\subsection{The three phases of sector globalisation}

The approach proposed here does not cover all the dimensions of the globalisation phenomenon, being confined to the most quantifiable aspects for which sectoral data are available.

A sector being made up of all the firms with the same main activity, bearing in mind the features of globalisation described in the previous chapter, it is possible to identify three phases in the globalisation of a sector. ${ }^{10}$ 
These are: $a$ ) the internationalisation of trade; $b$ ) the multinationalisation of production and $c$ ) the globalisation of innovation.

Internationalisation concerns any trade in goods and services or factors of production, and also transfers of information. It is a process governed mainly by means of a system of relative prices and by supply and demand.

Multinationalisation is a step further and involves the principle of production abroad. It implies the organisation and control of production and trading activities abroad by firms that are basically rooted in national economic systems. The main vehicle of multinationalisation is direct investment.

Globalisation proper is an even more advanced stage, implying a new form of social organisation of innovation. In order to develop their technologies and innovate, global firms derive their know-how from a number of information centres located in different countries. This phase is dominated by the location of numerous laboratories involved in research and innovation outside the country of origin. The more the purpose of these laboratories is to produce technologies intended for world markets, the more advanced is the globalisation of the sectors concerned.

It follows that, to calculate the degree of globalisation of a sector, it is necessary to take into account the main characteristics of the three phases mentioned above, i.e. international trade, direct investment and the geographical decentralisation of R\&D laboratories, which is just one aspect of the globalisation of innovation.

Before proposing indicators to characterise these three phases, a distinction must be drawn between the globalisation of an industrial sector and that of a product. While the degree of globalisation of a product depends upon demand for that product and its relative uniformity in markets, the globalisation of a sector depends upon the supply structure. The more a sector is oligopolistic (duopoly if not monopoly), the greater its tendency to remain at the international trade phase and the less incentive it has to move on to the multinationalisation of production or globalisation of innovation (e.g. aircraft). In contrast, the products of a highly globalised sector may be more regional than global in nature (e.g. cars).

\subsection{Measuring sector globalisation}

\subsubsection{International trade. ${ }^{11}$}

The indicators most frequently proposed concern:

- Export ratios (the share of production exported).

- The rate of import penetration (the share of imports in domestic demand).

- The rate of exposure to competition (a combination of the export ratio and the rate of import penetration).

- Intra-industry or intra-branch trade.

- Intra-firm trade. 
- Exports and imports of foreign affiliates at home.

- Exports and imports of affiliates of national firms abroad.

Amongst these indicators, the "export" ratio best reflects a sector's share in world trade and it can be applied equally to a sector or to an individual firm. On the other hand, both the import "penetration rate" and the "rate of exposure to competition" are more ambiguous because of imports.

More specifically, whereas exports relate to a particular sector and incorporate only the value of the goods and services exported, the measurements relating to imports have two major drawbacks.

The first is that imports cannot be attributed to a specific sector. Machine tool imports, for example, go to other sectors in addition to mechanical engineering, so that a country's imports of machine tools do not so much reflect its mechanical engineering industry's degree of internationalisation attributable to trade, but rather that of the exporting countries. The second drawback relates to import content. Unlike exports, imports include not only the value of the goods but also transport and insurance costs, so that the longer the distance and the greater the value of the goods, the higher the additional costs and the more they will impinge on domestic demand. For similar reasons, measurements of the rate of exposure to competition, which takes account of imports, do not in principle show a sector's degree of globalisation.

If imports are to be taken into account, it would be preferable to use:

- The share of imports of intermediate goods in overall consumption of such goods in each sector. The advantage of this category of imports is that the sector to which they go is clearly defined. The relevant share is measured by means of input-output matrices.

The indicator of intra-industry or intra-branch trade, which ranges from 0 to 100 , is important as a means of showing trade prompted by product differentiation. The more two countries trade identical goods and the closer the value of the said goods, the higher the indicator will be. In contrast, the more trade is unilateral, the lower the indicator will be. There can be no doubt that intra-industrial indices are high in countries with big per capita incomes, which are geographically close and where there is strong regional integration. However, the indicator does not necessarily show an industry's degree of globalisation -- mainly for the same reason as before in that imports are not ascribed to the sectors which export these products.

The intra-industrial indicator would say more about the degree of globalisation if it were applied to a product, without any reference to a particular sector. Also, it is more relevant at a fairly fine level of aggregation, where products are relatively similar, albeit highly differentiated. Sector level aggregation is to a certain extent distorted by the mix of products of a different nature deriving from both the primary and secondary activities of each sector.

The indicator of intra-firm trade, on the other hand, more accurately reveals a sector's degree of globalisation. It is usually in one of four forms, depending on whether it relates to each country's exports or imports or inward and outward investment. More specifically, it measures the share of trade between the parent company and affiliates in the same group in relation to the overall trade of the reference country.

In the present analysis, priority is given to exports of outward investment, i.e. the share of a country's parent companies' exports to all their foreign affiliates compared with that country's total exports in the same sector. The ratio of intra-firm exports to the total exports of a sector depends of course 
on the number and the size of affiliates abroad and also on the organisation of firms. We could assume that this ratio will be higher in the case of a vertical integration organisation and lower in the case of a horizontal one.

Other measurements of intra-firm trade which could also be considered include the share of a country's foreign affiliates' imports from their parent company abroad (or from other affiliates in the same group) in the host country's total imports, or the share of foreign affiliates' exports to the parent company and to the same group's other affiliates abroad in the host country's total exports.

The first of these two sorts of measurement has the same drawbacks as the majority of those involving imports. The second is more concerned with situations where the purpose of foreign affiliates in a given country is to transfer a significant proportion of their output to their parent companies or to other affiliates in the same group. In this respect, it is a measurement that could be used as an indicator of the globalisation of the sector to which the said affiliates belong.

All of these indicators concerning intra-firm trade reflect the weight of multinational firms (foreign or national) in a country's trade and, therefore, the degree of internationalisation of the sectors concerned. The economic significance of these indicators is also important insofar as intra-firm trade is not subject to the same competitive rules as other trade. This interpretation needs, however, to be qualified in that a large proportion of intra-firm trade is not specifically intended to meet parent company demand or that of other affiliates in the same group but, because of the latter's superior knowledge of the local market, they serve as a staging post for the trade flows which satisfy other firms and consumers.

Another feature of trade which supplements the export ratio is the geographical concentration of exports. Assuming equal quantities, a sector which exports to numerous countries is considered to be more internationalised than one which exports to few countries. One way of taking this property into account is to construct an indicator of the geographical concentration of exports using Herfindahl indices (Box 1).

The lower the values of the Herfindahl index (low concentration), the more internationalised the sector. Thus, the indices used to measure the internationalisation of the different sectors' trade are as follows:

- The export ratio (share of output exported).

- The index of geographical concentration of exports (Box 1).

- Imports of intermediate goods in total intermediate consumption.

- Intra-firm exports of nationally controlled firms.

- Foreign affiliates' intra-firm imports.

Since the last two measurements are available only for the United States, they have not been used in the calculations for other countries. 


\section{Box 1. The geographical concentration of exports}

(Herfindahl index)

$\mathrm{X}$ represents the total exports of country A from sector $\mathrm{j}$, which are destined for $\mathrm{n}$ different countries.

Herfindahl's index of geographical concentration for country A's exports from sector $\mathrm{j}(\mathrm{Hj})$ is the sum of the squares of the market shares held in each country of destination i compared with sector j's total exports, i.e.

$H_{j}=\left[\frac{\mathrm{X}_{1}}{\sum_{i=1}^{n} X_{i}}\right]^{2}+\left[\frac{\mathrm{X}_{2}}{\sum_{i=1}^{n} X_{i}}\right]^{2}+\ldots+\left[\frac{\mathrm{X}_{\mathrm{n}}}{\sum_{i=1}^{n} X_{i}}\right]^{2}$

If each of the $\mathrm{n}$ countries of destination received the same export value, the Herfindahl index would be equal to:

$H_{j}=\frac{1}{\mathrm{n}}$

Countries which receive very low export values influence the Herfindahl index very little and can if necessary be left out of the calculations.

\subsubsection{International investment}

Two categories of indicator are proposed where international investment is concerned: the first relating to inward and outward investment flows and stocks and the second to the activity of foreign affiliates, especially with regard to turnover and production. Data on investment flows and stocks are generally available only at a fairly high level of aggregation and are difficult to compare with other industrial data.

Data on activity, however, apart from being more disaggregated, allow more direct comparisons with sectoral industrial activity.

Two indicators of the activity of foreign affiliates are proposed:

- The share of foreign affiliates' production or turnover in the national total for each sector (inward investment).

- The share of the production or turnover of national firms' affiliates abroad in the production or turnover of the country as a whole or of all national firms in the same sectors (outward investment). This second indicator is available for only a very small number of countries which possess data on the activity of their affiliates abroad. 
Other indicators which could be used relate to foreign direct investment, and in particular international mergers and acquisitions, co-operation agreements and alliances between firms from different countries, but such data are not at present available to the Secretariat.

\subsubsection{The internationalisation of industrial $R \& D$}

As in the case of international investment, two indicators are proposed for the geographical decentralisation of industrial R\&D:

- The share of foreign affiliates' $R \& D$ in the total national $R \& D$ of each sector (inward investment).

- The share of the R\&D of national firms' affiliates abroad in the national total or in the total for national firms belonging to the same sectors in the country of origin (outward investment).

These two indicators show the degree of internationalisation of R\&D on the domestic market and on countries' foreign markets. They are of special importance in that, as was said above, R\&D is often the last activity that firms internationalise. ${ }^{12}$ 


\section{MAIN RESULTS}

The indicators used have been split into two categories, depending on whether they concern the globalisation of industry in each country's foreign markets or domestic market (Table 1).

In the first place, the indicators allow the countries to be ranked according to the degree of globalisation of their manufacturing industry as a whole. Secondly, on the basis of these indicators, a ranking is proposed of each country's industrial sectors, together with a number of conclusions regarding the OECD area as a whole.

\subsection{Internationalisation of the whole of manufacturing industry in the OECD countries}

It may be pointed out first of all that, where international trade is concerned, it is apparent from looking simultaneously at the export ratio and the geographical concentration of exports (Figure 4) that some of the smaller European countries were exporting more than half of their manufacturing output in 1994 (Belgium, Denmark, Finland the Netherlands and Sweden), whereas the export ratios of the very big countries -- mainly the United States and Japan, and also Australia -- were amongst the lowest at between 13 and 18\%. Although the export ratio is influenced by the size of the country, it would seem not to be the only factor involved. Australia, for example, exports less than the Netherlands despite being of much the same size in GDP terms. Canada is the country with the highest geographical concentration of exports (Figure 4) because over $80 \%$ of its manufacturing exports go to one country, the United States. This is to be compared with German, Finnish Swedish and UK exports which are the least concentrated geographically.

Looking at trends, between 1985 and 1994 export ratios rose in Canada and Finland but fell in Japan (from 14.5 to $12.5 \%$ (Figure 5). At the same time, the geographical concentration of Finnish and Japanese exports of manufactures fell while that of Austria -- one of the highest, in fact, in the OECD area -- rose. The export ratio increased appreciably in the other countries, while geographical concentration has on the whole evolved relatively little.

Where international investment and $R \& D$ are concerned, the indicators proposed in the previous chapter, and in particular those for outward investment, are available for only a small number of countries. This is why using the data for investment stocks (which are available only at aggregate level, including services), could give a more complete view of countries' internationalisation as regards foreign investment, both on foreign markets and the domestic market.

Figure 6, which measures the share of inward and outward direct investment stocks in relation to GDP in 1995, shows that some economies are more internationalised on foreign markets and some on the domestic market. 
Figure 4. Rate of exportation and Herfindahl index of geographical concentration of exports of the manufacturing sector, 1994

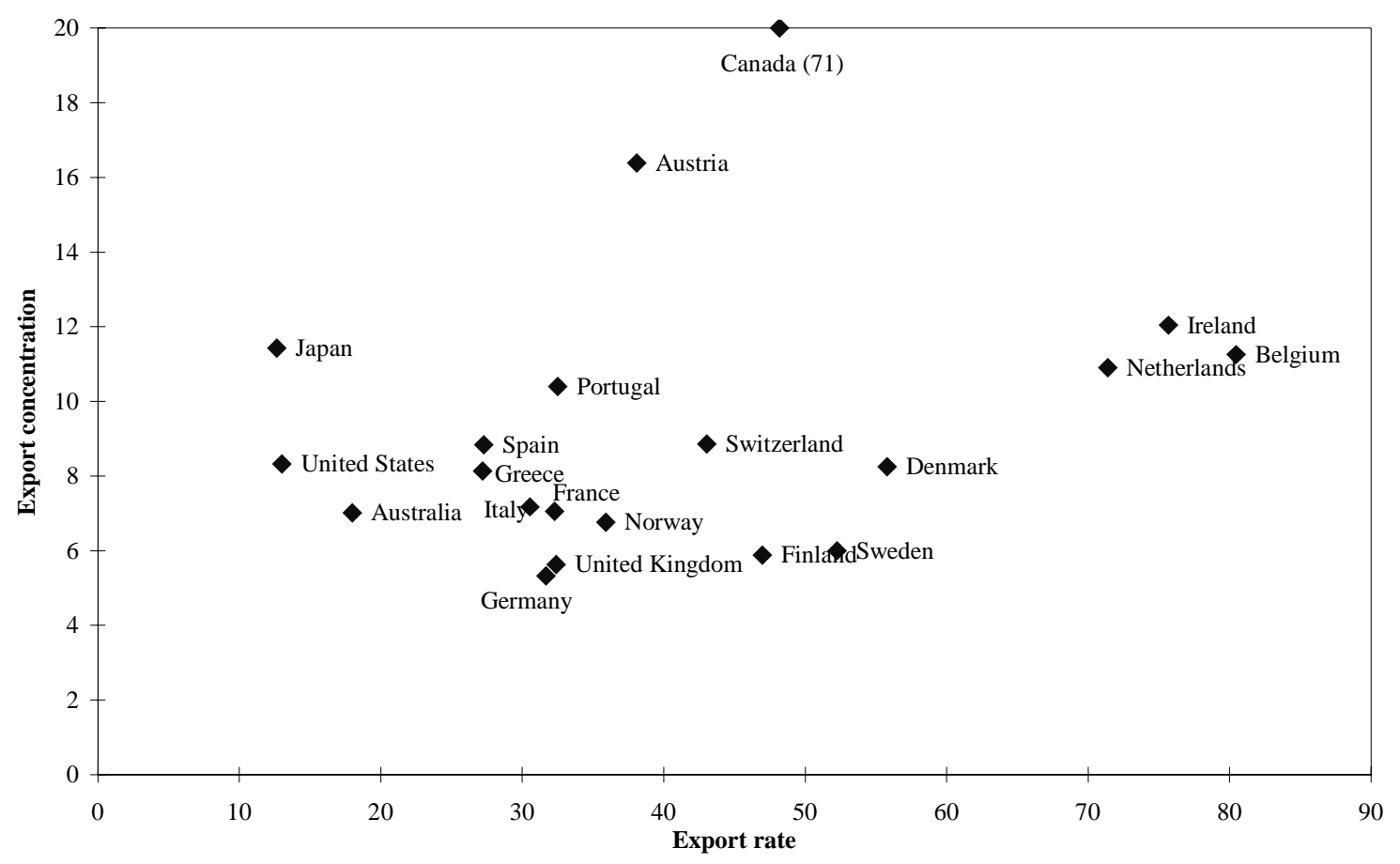

Source : OECD, BTD and STAN databases (DSTI/EAS Division).

Figure 5. Change in the Herfindahl index of geographical concentration of exports and of the rate of exports, manufacturing sector, 1985-94

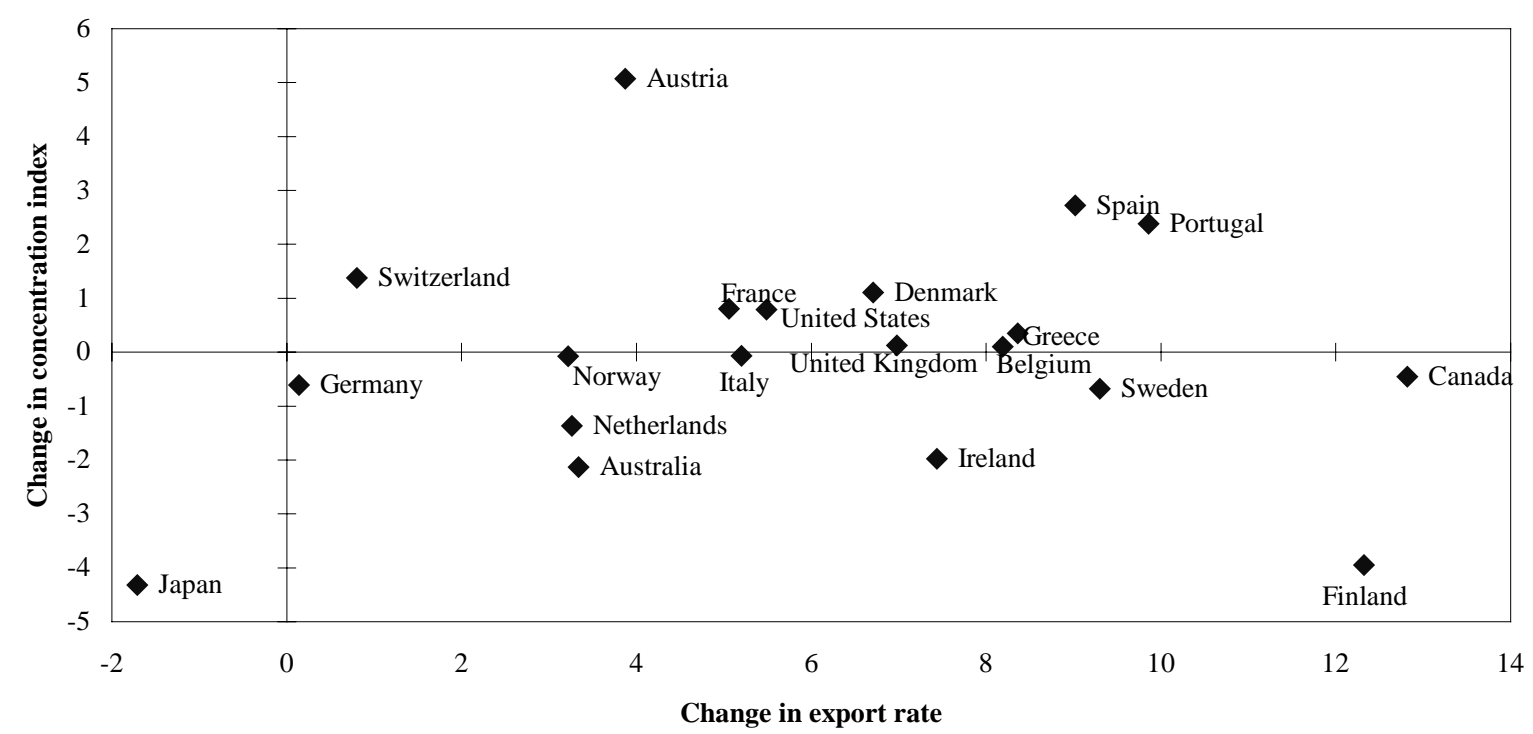

Source: OECD, BTD and STAN databases (DSTI/EAS Division). 
Figure 6. Share of direct inward and outward investment stocks in GDP, 1995

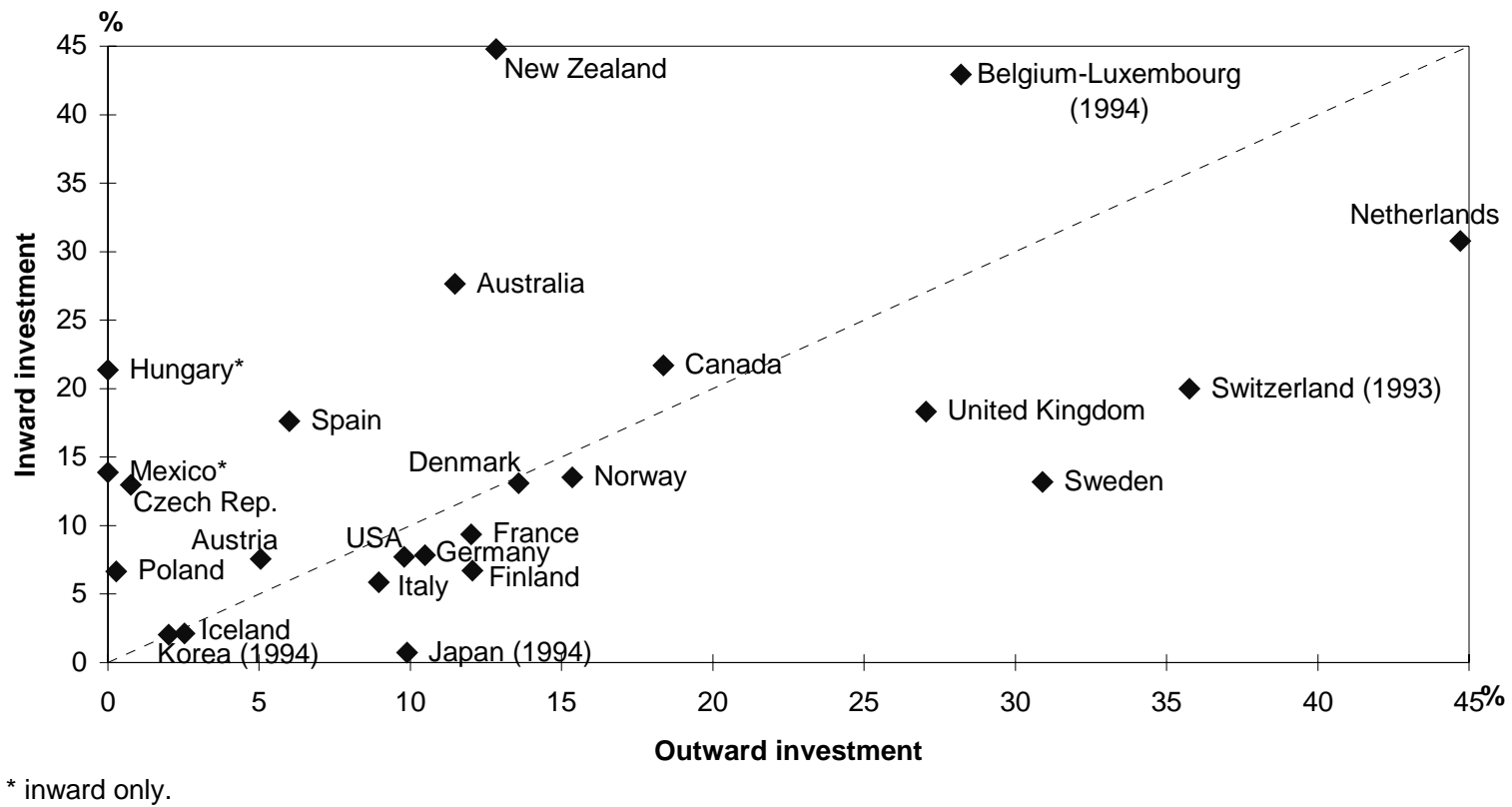

Source: OECD, AFA database (DSTI/EAS Division) and Foreign Investment database.

The United Kingdom, together with three other small European countries: the Netherlands, Sweden and Switzerland, invest comfortably more abroad than foreign countries invest in their territory. The above three countries are notable for having numerous multinational firms which invest massively abroad. Countries such as Australia, Belgium and New Zealand, on the other hand, receive a lot more foreign investment than they themselves invest abroad.

With regard to the internationalisation of industrial $\mathrm{R} \& \mathrm{D}$, only domestic market data are available for a significant number of countries. Figure 7 summarises countries' positions in 1994 in terms of the share of foreign affiliates' R\&D in each country's total manufacturing $R \& D$, and also in terms of the equivalent ratio for turnover.

The internationalisation of industrial R\&D on the domestic market, measured by the share of R\&D under foreign control, exceeds 70\% in Ireland and is close to $47 \%$ in Australia and $37 \%$ in Canada and the United Kingdom. On the other hand, it accounts for less than 10\% in Finland and Japan.

Table 1 shows countries' positions on both foreign markets and the domestic market. An overall classification of the different countries is not possible because of the lack of data in general and, more especially, data concerning foreign markets.

The data available do, however, show that, on the domestic market, manufacturing industry is more internationalised in the case of five countries, namely Australia Canada, Ireland, the Netherlands and the United Kingdom, whereas it is much less internationalised in the United States and less so still in 
Japan. That finding confirms the influence that country size has on the degree of internationalisation of the domestic market, but the United Kingdom again proves that the internationalisation phenomenon is also explained by other factors.

Taking account of geographical origin in the case of direct investment (this information is not available for other indicators) shows that foreign-controlled production is less concentrated in Australia, the Netherlands and the United Kingdom than in Canada and Ireland.

Whereas in the Netherlands, Australia and the United Kingdom, the five foremost foreign investors are responsible for 55, 79 and $80 \%$, respectively, of foreign-controlled production, in Ireland and Canada the corresponding figures are 88 and 92\%. Also, in Canada, Ireland and the United Kingdom, the United States is comfortably the biggest investor country, followed by the European Union, while in Australia and the Netherlands, it is the other way round.

Table 1 and Figures 4 and 6 show that the countries with the most internationalised manufacturing industry on foreign markets are Belgium, the Netherlands, Sweden, Switzerland, and the United Kingdom.

Other countries, such as Denmark and Finland, which export more than half of their manufacturing output, are still investing only moderately abroad by comparison with the preceding countries.

Figure 7. Share of expenditure of R\&D of foreign affiliates' turnover in R\&D expenditure and of turnover of total manufacturing industry, 1994 (or nearest year)

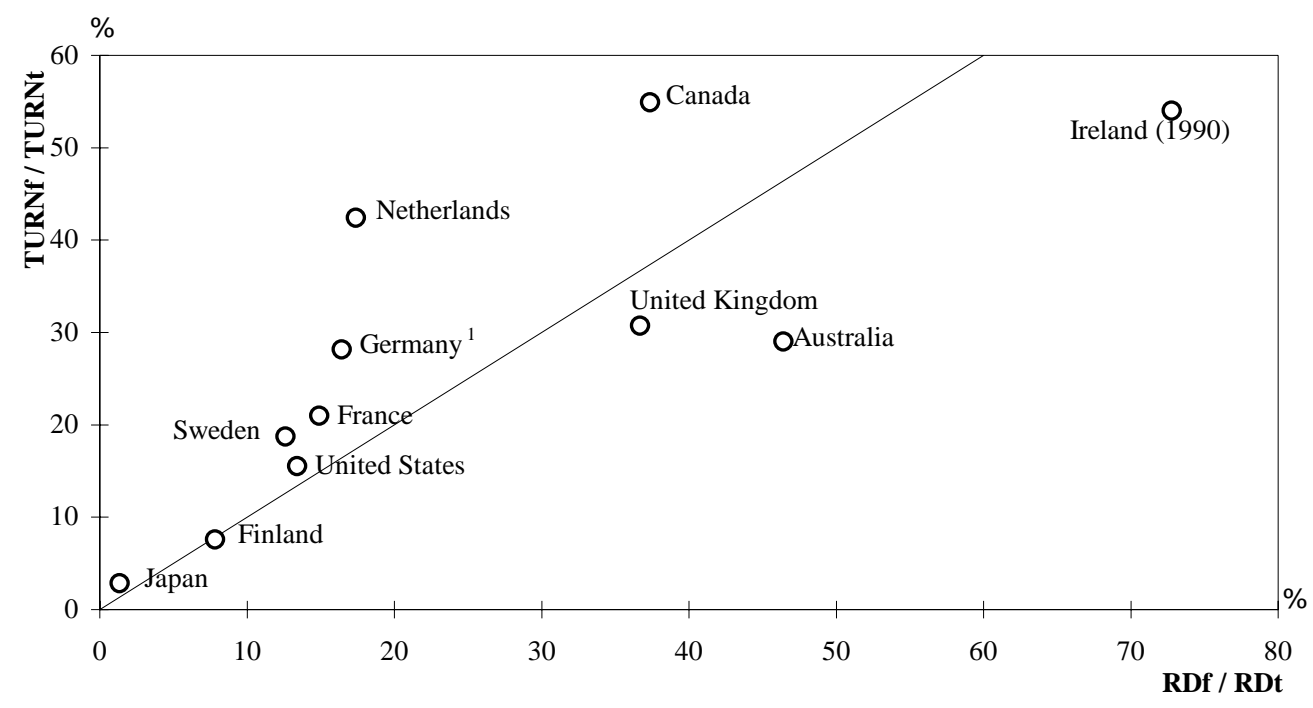

1. Sample of 500 most R\&D-intensive firms

Notes: TURNf/TURNt: foreign affiliates' turnover/total firms' turnover RDf/RDt: foreign affiliates' R\&D/total firms' R\&D

Source: OECD, AFA, STAN and ANBERD (DSTI/EAS Division databases). 
DSTI/DOC(99)2

Table 1. Indicators of globalisation for the total manufacturing sector, 1995 or latest year

\begin{tabular}{|c|c|c|c|c|c|c|c|}
\hline & \multicolumn{3}{|c|}{ Internal market } & \multicolumn{4}{|c|}{ External markets } \\
\hline & $\begin{array}{c}\text { Share of imports } \\
\text { of intermediate goods in } \\
\text { total interm. consumption }\end{array}$ & $\begin{array}{c}\text { Share of } \\
\text { production under } \\
\text { foreign control } \\
\end{array}$ & $\begin{array}{c}\text { Share of } \\
\text { R\&D under } \\
\text { foreign control }\end{array}$ & Export rate & $\begin{array}{c}\text { Export } \\
\text { concentration } 2\end{array}$ & $\begin{array}{c}\text { Direct } \\
\text { investment }^{3}\end{array}$ & $R \& D^{4}$ \\
\hline United States & 10.45 & 12.21 & 13.90 & 13.03 & 8.3 & 9.79 & 10.65 \\
\hline Canada & 27.17 & 54.32 & 37.37 & 48.19 & 71.1 & 18.37 &.. \\
\hline Mexico &.. & 17.96 &.. &.. &.. &.. & .. \\
\hline Japan & 9.53 & 2.80 & 1.33 & 12.66 & 11.4 & 9.89 & 2.10 \\
\hline Korea &.. &.. &.. &.. & .. & 2.00 & .. \\
\hline Australia & 16.80 & 29.00 & 46.39 & 17.99 & 7.0 & 11.47 & .. \\
\hline New Zealand &.. &.. & .. & 38.54 & 8.9 & 12.83 &.. \\
\hline Austria & .. & .. &.. & 38.08 & 16.4 & 5.05 &.. \\
\hline Belgium & .. & .. & .. & 80.48 & 11.3 & 28.20 & .. \\
\hline Czech Republic & .. & .. & .. & .. & .. & 0.76 & .. \\
\hline Denmark & 32.90 &.. &.. & 55.81 & 8.2 & 13.58 &.. \\
\hline Finland &.. & 10.11 & 12.15 & 46.98 & 5.9 & 12.05 & .. \\
\hline France & 23.59 & 23.92 & 18.50 & 32.28 & 7.1 & 12.01 &.. \\
\hline Germany ${ }^{5}$ & 18.95 & 28.14 & 16.45 & 31.69 & 5.3 & 10.48 &.. \\
\hline Greece &.. &.. & 9.79 & 27.20 & 8.1 &.. &.. \\
\hline Hungary & .. & .. &.. &.. &.. & .. &.. \\
\hline Iceland & .. &.. & .. & 50.91 & 11.1 & 2.54 & .. \\
\hline Ireland & .. & 53.98 & 71.43 & 75.57 & 12.0 & .. & .. \\
\hline Italy & 27.56 & 19.30 & .. & 30.55 & 7.2 & 8.95 & .. \\
\hline Netherlands & 44.75 & 40.89 & 17.42 & 71.38 & 10.9 & 44.71 &.. \\
\hline Norway &.. & 11.60 &.. & 35.90 & 6.8 & 15.35 &.. \\
\hline Poland ${ }^{6}$ &.. &.. & 1.94 &.. &.. & 0.28 &.. \\
\hline Portugal & .. & .. &.. & 32.53 & 10.4 & .. &.. \\
\hline Spain & .. &.. & 32.70 & 27.27 & 8.8 & 6.00 &.. \\
\hline Sweden & .. & 18.58 & 11.86 & 52.26 & 6.0 & 30.90 & 27.80 \\
\hline Switzerland & .. & .. & .. & 43.03 & 8.9 & 35.75 &.. \\
\hline Turkey &.. & 11.14 & 16.22 & 22.45 & 7.7 &.. &.. \\
\hline United Kingdomn & 26.82 & 31.04 & 36.73 & 32.39 & 5.6 & 27.05 &.. \\
\hline
\end{tabular}

1. 1990 or latest year.

2. Geographical concentration of exports: Herfindahl index.

3. Share of the stock of outward investments in GDP.

4. Share of R\&D of affililiates of national firms abroad in total national R\&D.

5. Sample of $500 \mathrm{R} \& D-i n t e n s i v e$ firms.

6. Total industry.

Source: OECD, AFA, Input-Output, ANBERD, FDI and STAN databases. 


\subsection{Results by country ${ }^{13}$}

In the presentation by country, the aim is to classify manufacturing industries according to their degree of internationalisation on both the domestic and foreign markets. The indicators used for this purpose are the same as those shown in Table 1.

This approach, which is the first stage of work designed to establish links between the degree of internationalisation of industrial sectors and their performance, has numerous limitations attributable to the state of the basic data.

The first such limitation has to do with the absence of data concerning the activity of multinational firms in numerous countries, that lack of information relating more to R\&D activities than to production. Each country's industries, for example, have been classified not according to the same indicators for every country, but according to whatever indicators were available.

Another difficulty is the comparability of a given country's data, those for the national total not being systematically comparable with data for $R \& D$ and for foreign affiliates. While some data concerning the national total are put together at establishment level, R\&D and foreign affiliate data are prepared at firm level. This problem relates mainly to calculations concerning the share of the different sectors' production under foreign control. The comparability of a given country's data can sometimes be affected by the different levels of aggregation of the variables used. This problem is mentioned whenever appropriate in the country presentations.

Generally speaking, the lack of information concerning both services and also other important aspects of globalisation such as mergers and acquisitions, international subcontracting, collaboration agreements, joint ventures and strategic alliances, can limit the comprehensiveness of the results obtained.

\subsection{1. $\quad$ United States}

For the United States, two additional indicators have been used: the share of foreign affiliates' intra-firm imports in total imports in the case of the domestic market, and the share of national firms' intra-firm exports in total exports in the case of foreign markets (Annex Table 1). Concerning these two indicators, one should bear in mind the comments pointed out above (Section 2.3.1).

Combining the industrial sectors' rankings on both the domestic and foreign markets shows that pharmaceuticals are the most internationalised manufacturing industry, while the two least internationalised sectors are wood/furniture and paper/printing (Figure 8).

The pharmaceutical industry is the most internationalised on both markets. On the domestic market, its share in production and in R\&D under foreign control, and also the share of intra-firm imports in total imports are the highest recorded. On the other hand, it imports fewer intermediate products than most other industries in relation to its total consumption. Concerning foreign markets, it exports little but is solidly installed there, which is in line with horizontal integration organisation motivated by national regulations in this industry. Moreover, $80 \%$ of its exports go through affiliates, while R\&D performed abroad accounts for more than $26 \%$ of R\&D carried out in the United States (Figures 9 and 10).

As in the majority of countries, basic chemicals and electrical engineering are among the most internationalised industries -- almost as much so on the domestic market as on foreign markets. 
DSTI/DOC(99)2

Figure 8. Classification of manufacturing sectors in the United States according to their degree of internationalisation

\section{Ranking}

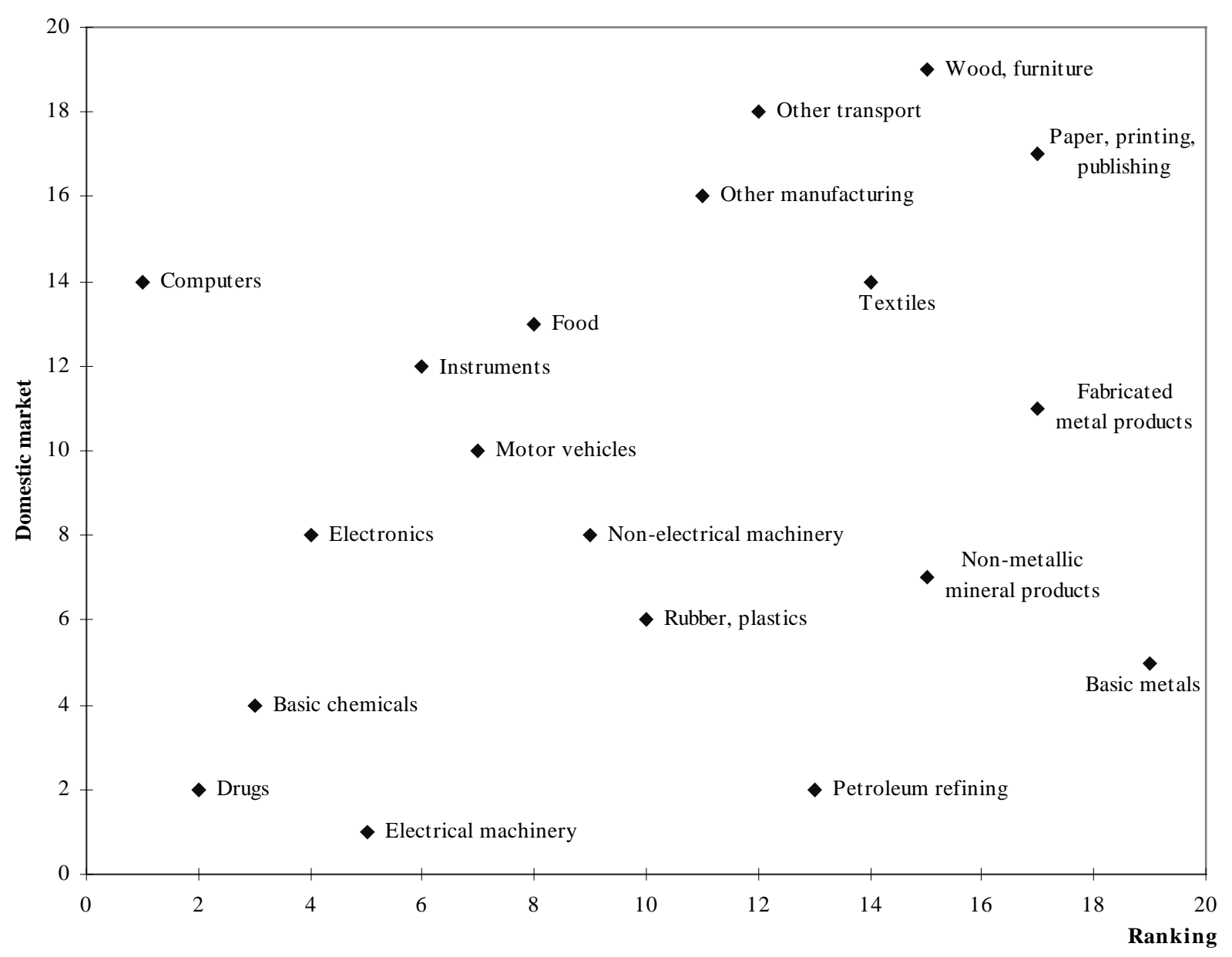

Source: OECD, AFA, Input-Output, ANBERD and STAN databases(DSTI/EAS Division).

The computer industry is the most internationalised on the domestic market. It is practically the only industry which both exports almost half of its domestic output, while its foreign affiliates produce the equivalent of $80 \%$ of the output of all firms in the United States. In contrast, the R\&D of its foreign affiliates corresponds to some 5\% of R\&D performed in the United States. There are few foreign affiliates on the domestic market, just 5\% of firms being under foreign control -- doubtless because of the dominant position of the United States in this sector. 
Figure 9. Concentration of exports and export rate by sector in the United States, 1994

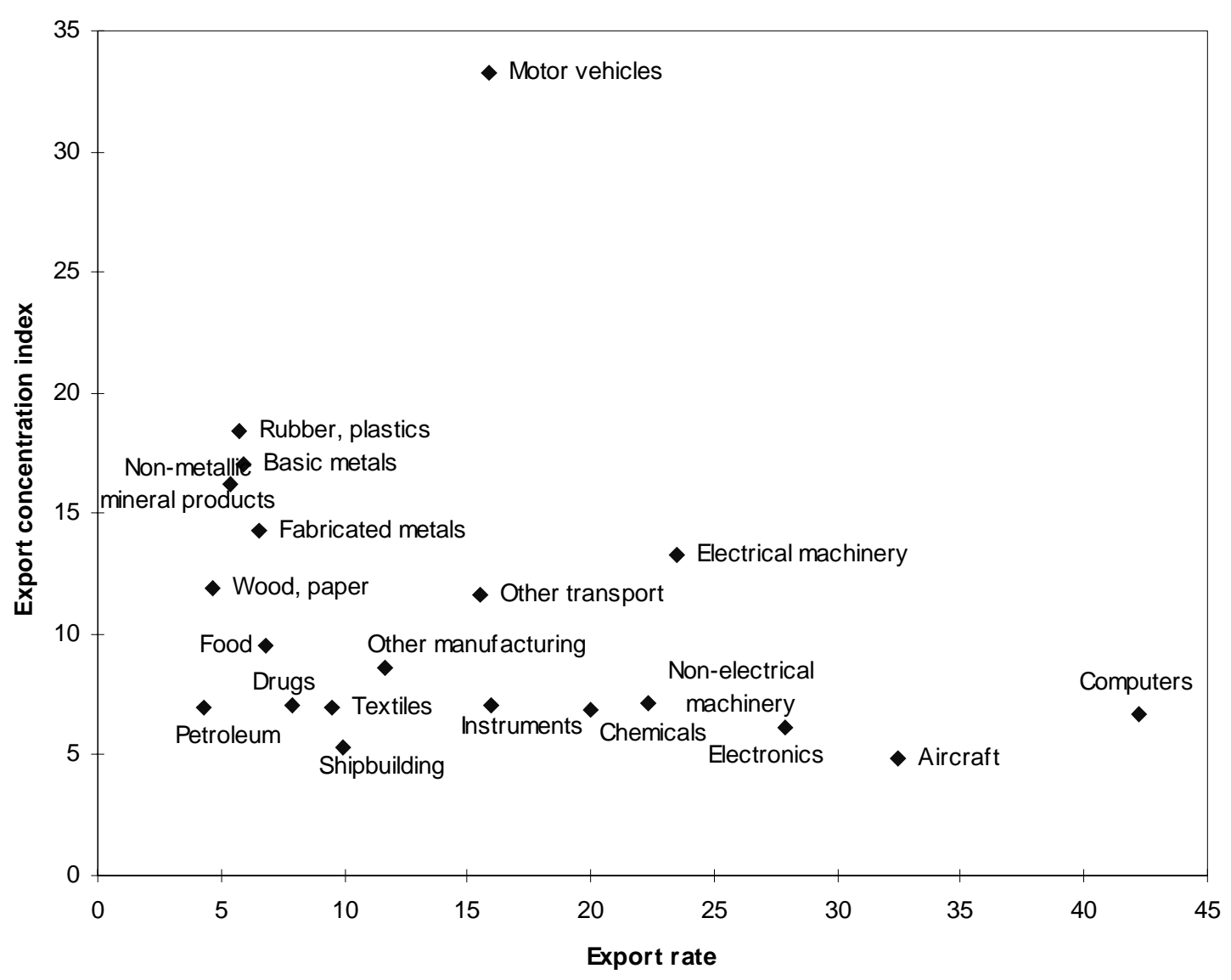

Source: OECD, BTD and STAN databases.

The electronics industry is also among the most internationalised -- more on foreign markets than on the domestic market. It needs to be emphasised though that, in this sector, spending on R\&D under foreign control in the United States is twice as high as R\&D expenditure by American affiliates abroad.

Two other fairly highly internationalised industries are the motor vehicle and petroleum refining industries. If the automobile industry is not one of the most internationalised sectors, it is because there is relatively little foreign presence on the domestic market in this industry. Although some countries have set up new production units, overall production under foreign control was no more than $9 \%$ of the national total in 1995, while the share of R\&D was only $1.7 \%$. On foreign markets, on the other hand, American affiliates accounted for more than $40 \%$ of production in the United States and $20 \%$ of R\&D. The motor vehicle industry does not, however, export very much (16\%), and the geographical concentration of exports is quite high because over $56 \%$ of exports go to just one country -- Canada (Figure 9). A moderate proportion of the domestic petroleum-refining industry is under foreign control, but foreign affiliates in the United States import a lot of intermediate products from their parent companies abroad. It may be noted that American affiliates produce as much abroad as all the firms in this sector in the United States (Figure 10). 
Figure 10. Turnover rate of R\&D expenditure of American affiliates abroad compared with national total broken down by sector, 1995

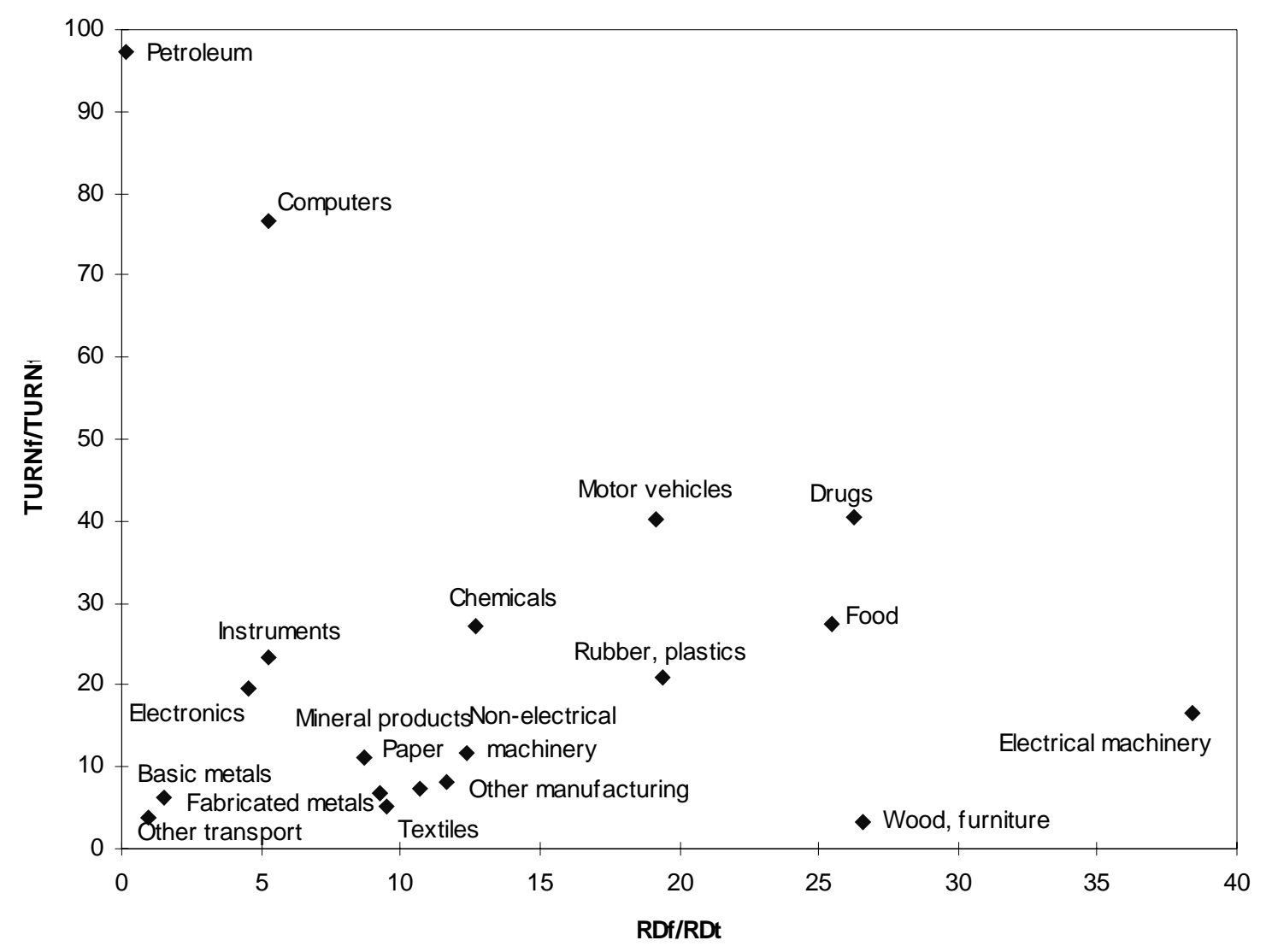

Source: OECD, AFA, ANBERD and STAN databases (DSTI/EAS Division).

Other sectors which are averagely internationalised include: non-electrical machinery, scientific instruments, the food industry and non-metallic mineral products. The rubber and plastics and non-metallic minerals industries are more internationalised on the domestic market, and the scientific instruments industry more on foreign markets.

In the United States, as in other countries, a number of industries are only slightly internationalised. These are the wood and furniture, paper and printing and metal products industries.

The other transport industry consists predominantly of the aircraft industry, which is a hightechnology industry that is not ranked among the most internationalised industries. As emphasised above, this industry, which corresponds to a single manufacturer (composed of a large number of firms and sub-contractors), is primarily export-oriented (over 30\% of production exported) (Figure 9), but does not produce abroad, and there is very little direct investment in the United States in this sector. As a result, there is not really any technology transfer or geographical decentralisation of R\&D where this particular industry is concerned. 
This preliminary classification of American manufacturing industries on the basis of their degree of globalisation shows that, with the exception of the aircraft industry, there is a link between the technological level and the level of internationalisation. If, moreover, the available indicators are weighted differently, i.e. if for example exports are given a coefficient of 1 , direct investment a coefficient of 2 and $\mathrm{R} \& \mathrm{D}$ decentralisation a coefficient of 3 , bearing in mind the different stages in the globalisation process, it transpires that the sector classification does not change that much, with the exception of the food industry whose degree of internationalisation improves appreciably with the changed weighting.

\subsubsection{Japan}

The indicators taken into account for Japan are less numerous than for the United States. The main difficulty concerning sector classification is that the industrial classifications of foreign investment in Japan (inward investment) and of foreign investment (outward investment) are different. Whereas the former is compatible with that of national industries in Japan, the second, the composition of which is different, makes it impossible to calculate -- for each sector -- the share of production by Japanese affiliates abroad in national output by all firms in Japan. This difficulty, combined with the lack of data on intra-firm trade, somewhat lessens the relevance of the results obtained -- particularly since Japanese industries are much more internationalised on foreign markets than on the domestic market. This is why only indicators relating to trade have been used to assess the internationalisation of sectors on foreign markets (Annex Table 2).

The overall classification shows that the most internationalised industry is the basic chemicals industry, both on foreign markets and on the domestic market. Other very internationalised sectors include non-electrical machinery (machine tools), electrical and electronic machinery and scientific instruments. Japan is highly specialised in these three groups of industries, which are those that record some of the highest export ratios.

Other industries, including plastics, basic metals and transport, are also fairly internationalised, but more on foreign markets. In the sectoral breakdown, failure to separate the motor vehicle sector from other transport and the lack of comparable data on outward investment mean that the scale of the internationalisation of this industry is greatly underestimated, despite it being -- along with electronics -one of the industries most strongly established abroad. From the trade standpoint, the motor-vehicle-sector dominated transport industry has one of the highest export ratios (share of production exported), but is very concentrated geographically (Annex Table 2), 45\% of Japanese car exports going to the United States, $17 \%$ to Asia and another $17 \%$ to Europe, of which $4 \%$ to Germany, $3.5 \%$ to the United Kingdom and $0.7 \%$ to France.

The pharmaceutical and petroleum refining industries are, in overall terms, not very internationalised, but the contrast on the two types of market is very strong. On the domestic market, foreign presence is very high in both sectors (22 and $44 \%$, respectively), while on foreign markets their internationalisation is very slight, even taking account of the presence of Japanese firms abroad (Annex Table 2).

The least internationalised sectors are the wood and furniture, textiles, paper and printing and food industries. Figures 12 and 13 show that if account had been taken of the establishment of Japanese industries abroad and of the research carried out by these industries outside Japan, the classification would not really have been very different. The industries identified as being the most internationalised are those which are more extensively established abroad (electrical and electronic machinery, chemicals and pharmaceuticals, transport, non-electrical machinery) and which perform $R \& D$ in the countries in which they are located. 
Figure 11. Classification of manufacturing sectors in Japan according to their degree of internationalisation

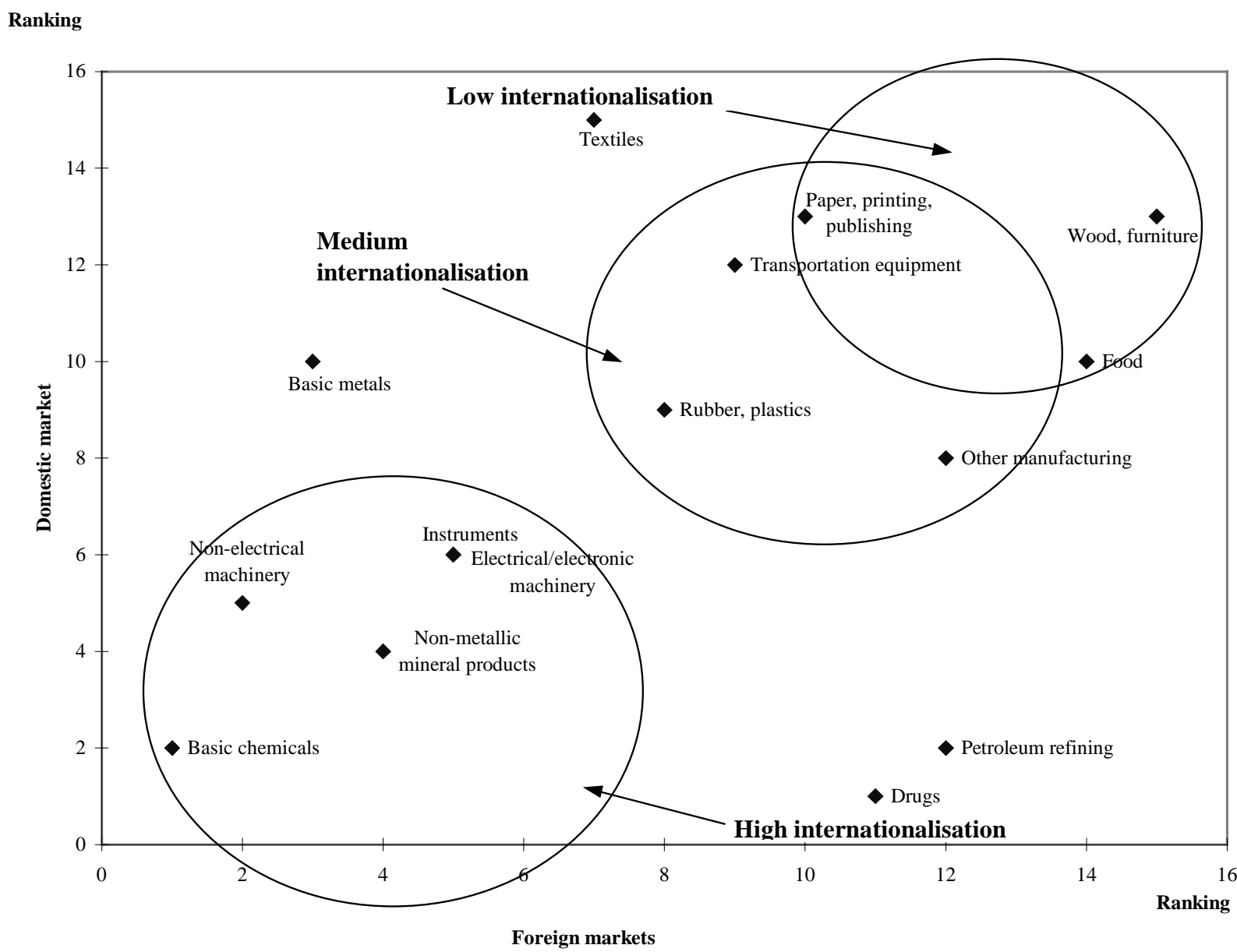

Source: OECD, AFA, Input-Output, ANBERD and STAN databases (DSTI/EAS Division). 
Figure 12. Turnover of Japanese firms abroad, by industrial sector

Billion yen, fiscal year 1993

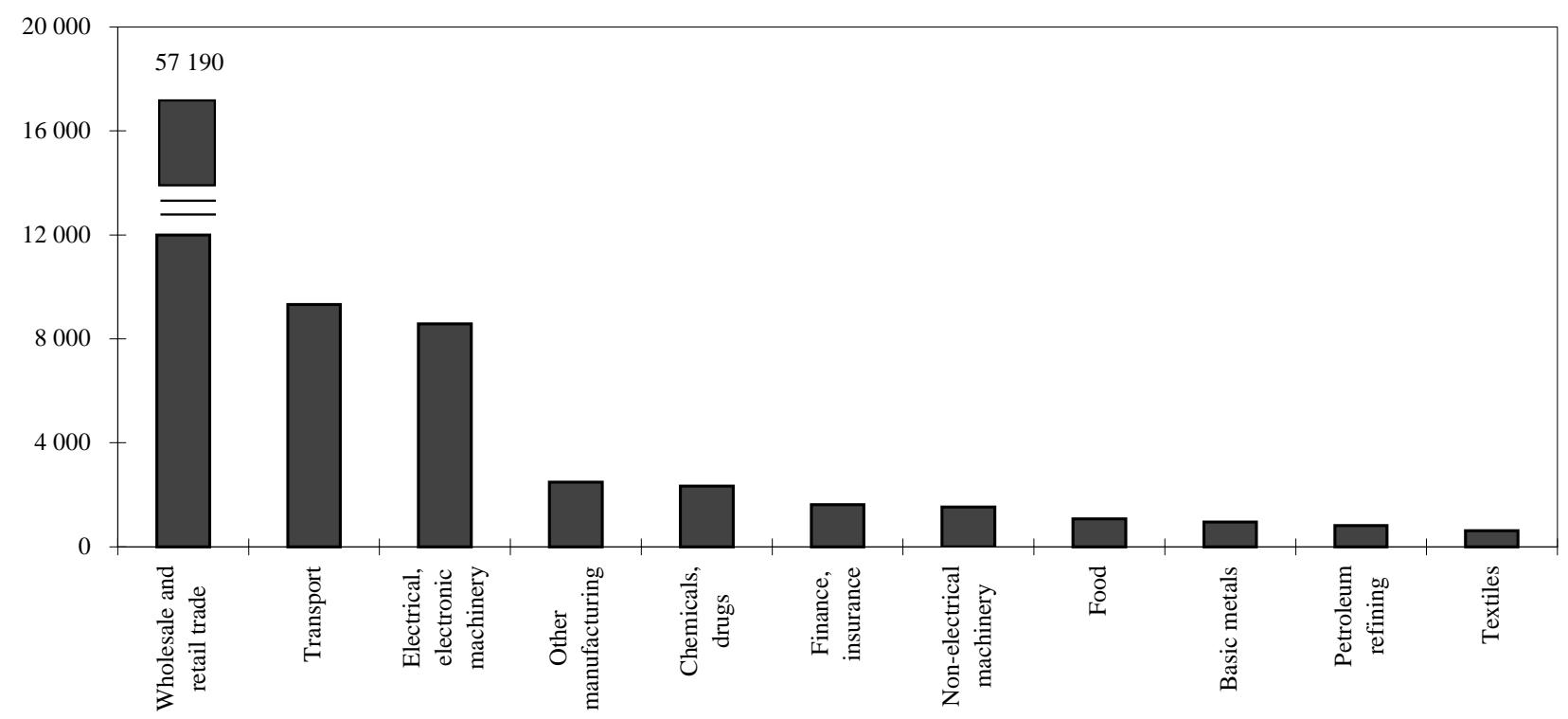

Source: OECD, AFA database (DSTI/EAS Division).

Figure 13. R\&D expenditure of Japanese firms abroad, by industrial sector

Billion yen, fiscal year 1993

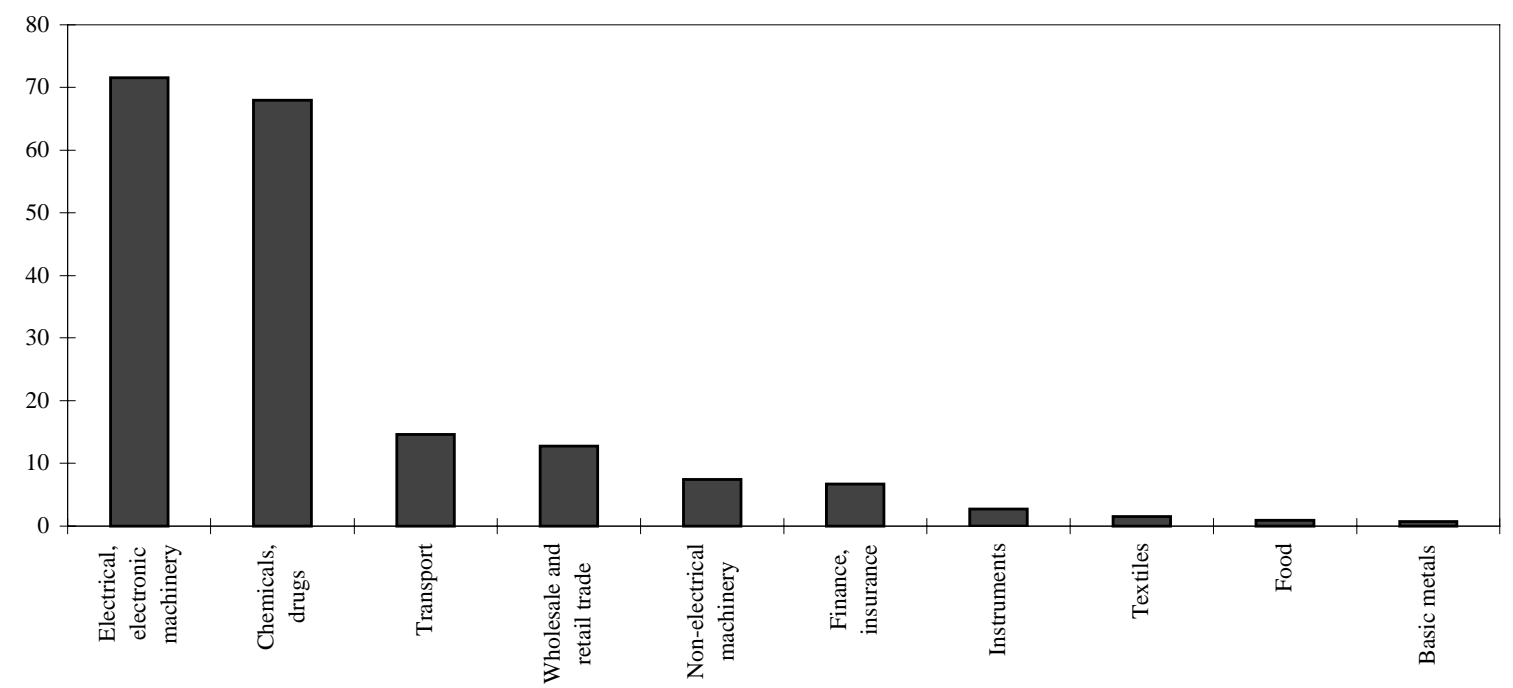

Source: OECD, AFA database (DSTI/EAS Division). 


\subsubsection{Germany}

In Germany too, the most internationalised industry is the basic chemicals industry (Figure 14) which also has the biggest comparative advantages. The internationalisation of the chemicals industry concerns both the domestic market and, especially, foreign markets. Almost half of their production is exported, while German chemicals affiliates produce the equivalent of $40 \%$ of the output of all the firms in this sector in Germany. Three of the other most internationalised industries include motor vehicles, scientific instruments and other manufacturing industries. The motor vehicle industry exports more than three-quarters of its production and is well established in numerous countries while, on the domestic market, more than one-quarter of the sector is foreign-controlled.

Figure 14. Classification of manufacturing sectors in Germany according to their degree of internationalisation

Ranking

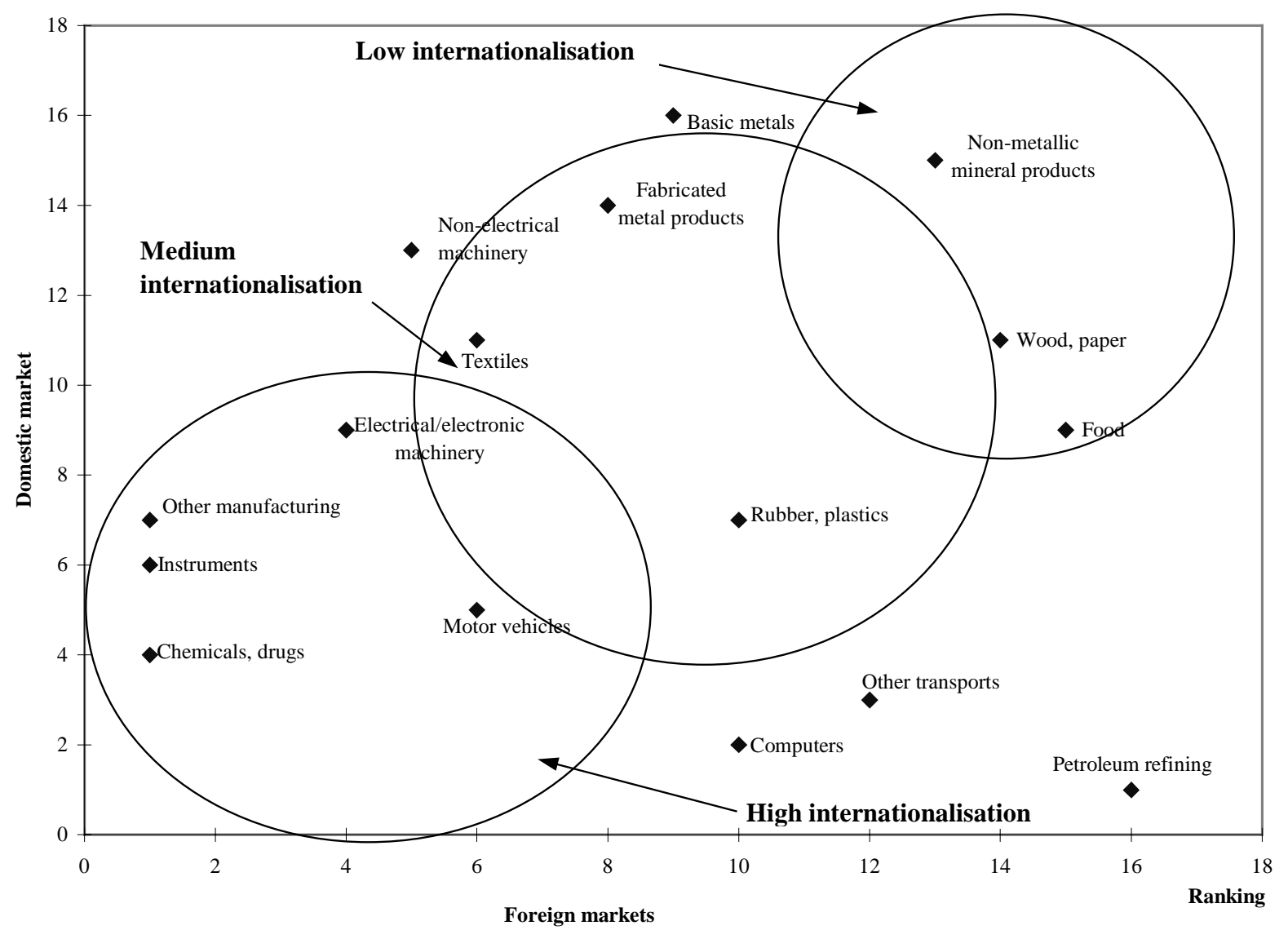

Source: OECD, AFA, Input-Output and STAN databases (DSTI/EAS Division). 
These results to some extent confirm Germany's strong position in all these sectors, in particular chemicals and motor vehicles. The computer industry is very internationalised on the domestic market (40\% of production is under foreign and mainly American control), but on foreign markets its internationalisation still very largely concerns the export phase, very few firms being set up abroad. The electrical and electronic machinery industry is almost equally internationalised on foreign markets and the domestic market, while the petroleum-refining industry is more internationalised on the domestic market (Figure 14).

As in most other countries, it is the low-technology sectors, in particular wood and paper and food industries, which are the least internationalised. Since the data on the geographical decentralisation of R\&D were too aggregated, they were not taken into account, which could slightly alter the final classification of industrial sectors.

\subsubsection{France}

In the case of France, the information available relates more to the domestic than to foreign markets. The French authorities have collected data on the production of French affiliates abroad and their intra-firm trade, but the said data are available in a nomenclature which is very different from the ISIC Rev. 2 used in this study. That apart, France is the only country to have tried to classify sectors by degree of globalisation. ${ }^{14}$ For this, two criteria were used:

a) Intra-branch trade ${ }^{15}$ when it was in excess of $33 \%$ and covered at least four geographical areas.

b) The contribution of intra-firm trade15 to intra-branch trade when in excess of $15 \%$ and covering at least four geographical areas.

When these criteria are applied to 105 industrial branches, only 12 meet both criteria at once, these being the following. ${ }^{16}$

- Electronic components (electronics).

- Motors, generators and transformers (electrical apparatus).

- Pharmaceutical products (pharmaceuticals).

- Various industries, writing materials.

- Basic chemical products (basic chemicals).

- Other electrical machinery (electrical apparatus).

- Agricultural machinery (non-electrical machinery).

- Ferrous metals (basic metals).

- Medical, surgical and orthopaedic equipment (scientific instruments).

- Rubber products (rubber, plastics).

- Household appliances. 
- Other chemical products (basic chemicals).

The criteria used in this report (Annex Table 4) show that eight manufacturing sectors could be considered to be among the most internationalised (Figure 15). First, scientific instruments and non-electrical machinery are generally very internationalised -- especially on foreign markets. The scientific instruments industry exports over $74 \%$ of its production to numerous countries (its geographical concentration is one of the lowest) (Figure 16). Next come the basic chemicals and electrical apparatus industries. On the domestic market, over $50 \%$ of basic chemicals are under foreign control and $56 \%$ of production is exported.

Figure 15. Classification of manufacturing sectors in France according to their degree of internationalisation

Ranking

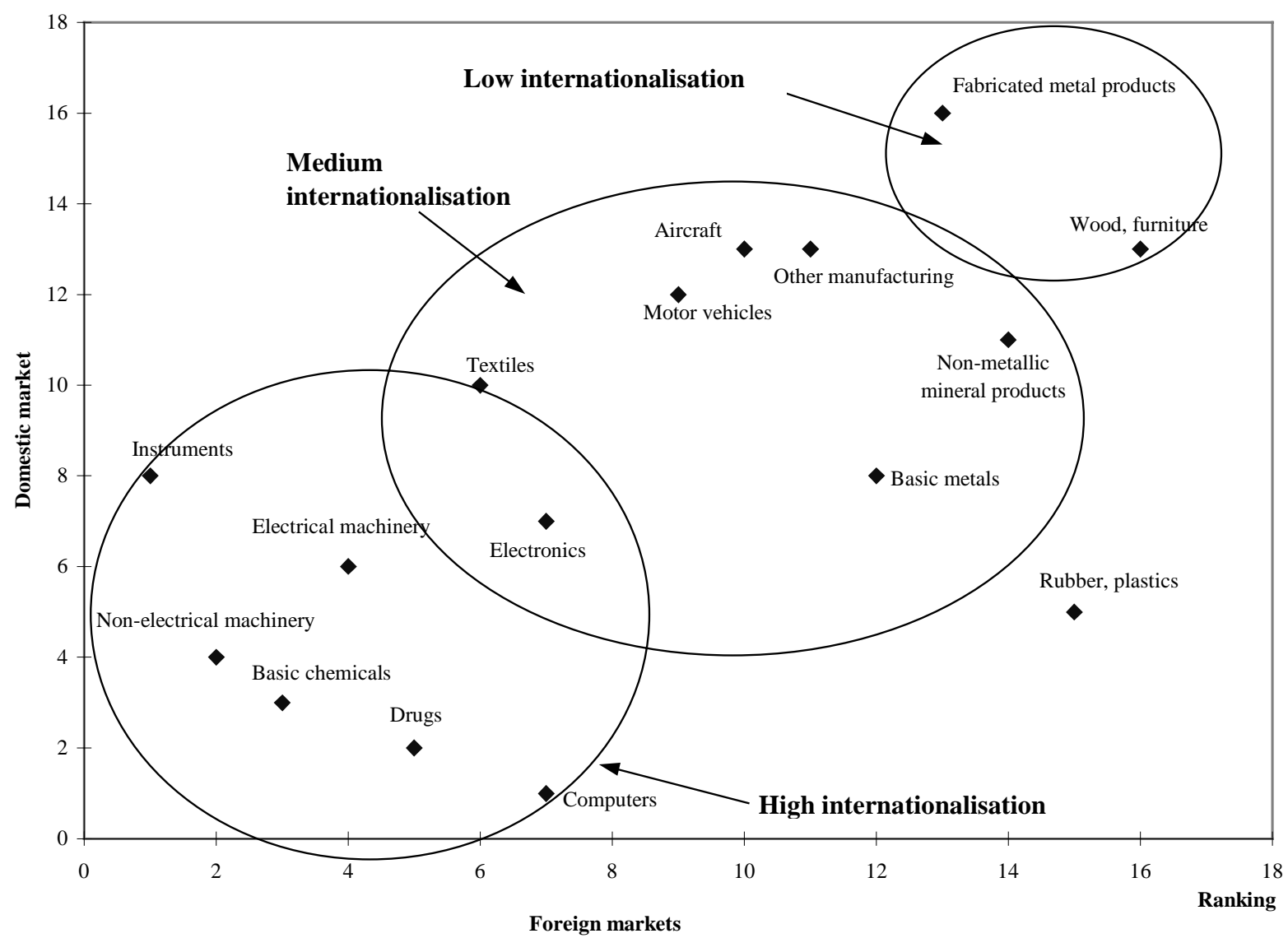

Source: OECD, AFA, Input-Output, ANBERD and STAN databases (DSTI/EAS Division). 
In the computer and pharmaceuticals industries, foreign presence in the French market is higher than in any other sector ( 75 and $63 \%$, respectively), while more than half of pharmaceutical industry R\&D and at least $35 \%$ of that performed by the computer industry are foreign-controlled. Lastly, the electronics industry, which is another highly internationalised sector, is mainly involved in industrial electronics and telecommunications equipment.

It will be noted that eight of the 12 branches that France includes in the globalised industries category belong wholly or partially to the highly internationalised sectors identified in the present study, though using different indicators. Amongst the low-technology sectors, only the textile industry is very internationalised -- and mainly on foreign markets. Two other important industries that are classified as averagely internationalised are the aircraft and motor vehicle sectors. What they have in common is that they are both more export-oriented and are not at all solidly established abroad (foreign markets). In both these sectors, inward foreign investment is also limited (Annex Table 4).

Figure 16. Concentration of exports and export rate by sector in France, 1994

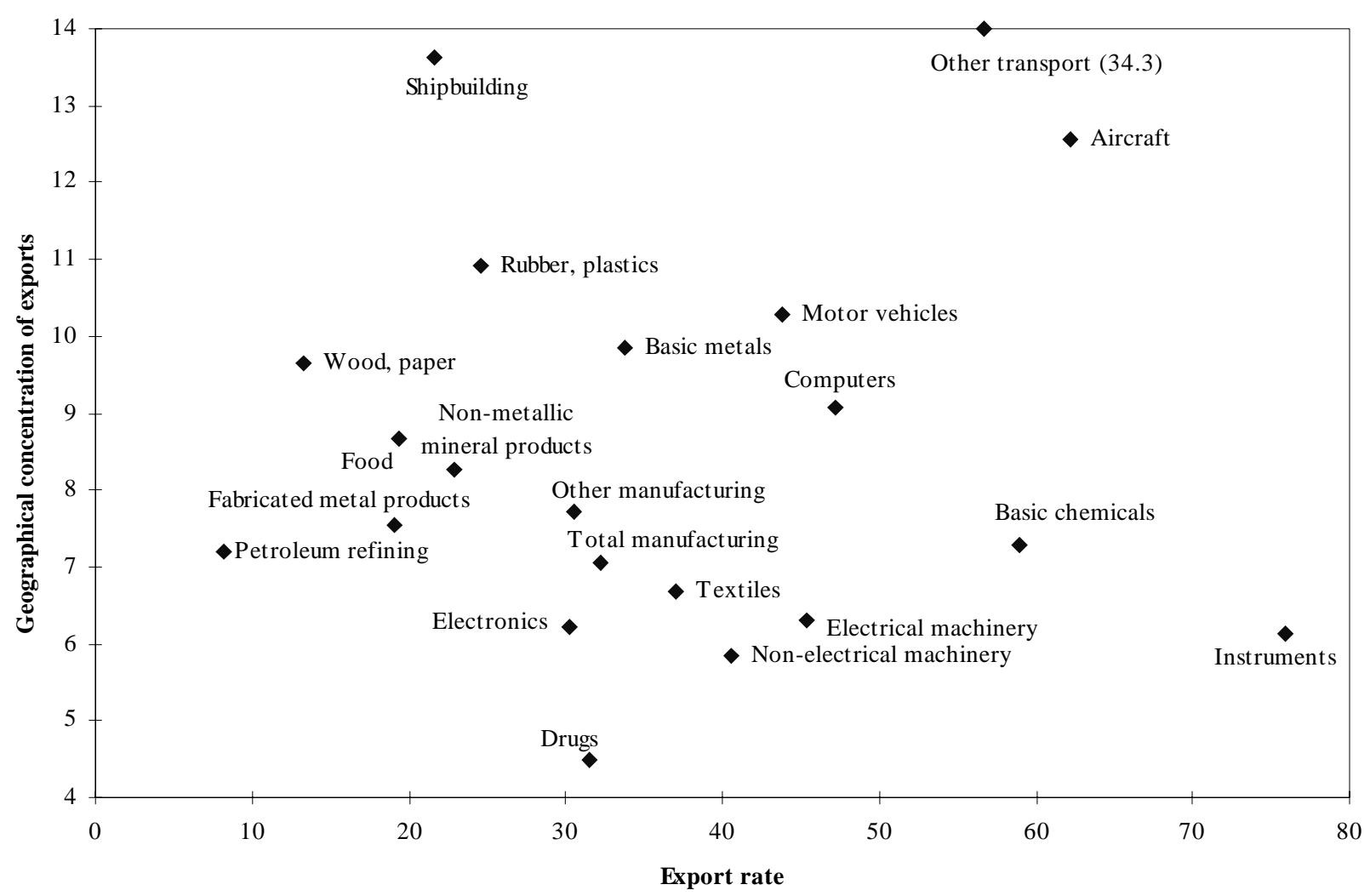

Source: OECD, BTD and STAN databases (DSTI/EAS Division). 


\subsubsection{United Kingdom}

British industry generally is the most internationalised of the G7 economies, that internationalisation being more evident on foreign markets, although the United Kingdom continues to receive more foreign investment than the other European countries.

Sectorally, the most internationalised industries are, in the following order: the computer, scientific instruments, electronics, motor vehicle and chemicals/pharmaceuticals industries -- in other words, all the high and medium-high technology sectors, with the exception of aircraft which is included under other transport (Figure 17).

Figure 17. Classification of manufacturing sectors in the United Kingdom according to their degree of internationalisation

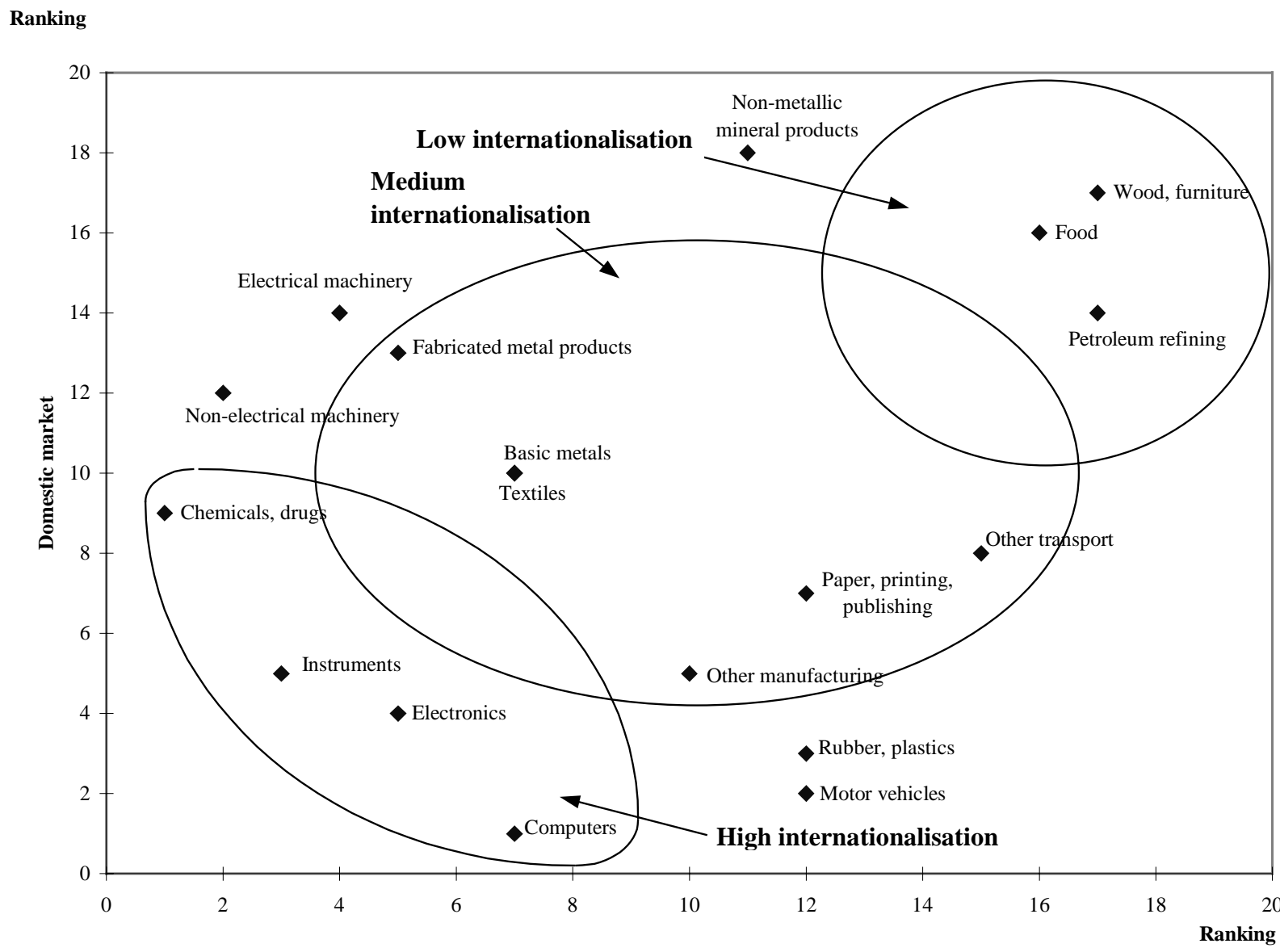

Foreign markets

Source: OECD, AFA, Input-Output and STAN databases (DSTI/EAS Division). 
The computer industry is the most internationalised on both the domestic market and also foreign markets, if only trade is taken into account. On the British market, the industry is over $75 \%$ foreign-controlled, with regard to both production and $\mathrm{R} \& \mathrm{D}$, and intermediate consumption includes over $42 \%$ of imported products. The industry also exports three-quarters of its production (which is the highest rate for all sectors), but its exports are relatively concentrated geographically. The internationalisation of the electronics and scientific instruments industries is comparable on both categories of market. The chemicals/pharmaceuticals and non-electrical machinery industries, on the other hand, are more internationalised on foreign markets, while the motor vehicle and rubber and plastics industries are mainly internationalised on the domestic market.

As in most countries, it is the low-technology sectors which are the least internationalised, the exceptions being textiles and basic metals which are averagely internationalised.

\subsubsection{Italy}

In Italy, the most internationalised industries are electronics, chemicals/pharmaceuticals, non-electrical machinery (machine tools) (Figure 18). All of these sectors are almost equally internationalised on both the domestic and foreign markets.

With the exception of the machine tools (non-electrical machinery) sector, where Italy also enjoys comparative export advantages, the internationalisation of other industries depends mainly on the sectoral effect rather than on the specialisation of Italian industry.

The textiles/clothing industry, in which Italy is the most highly specialised (three times more than the OECD average), is averagely internationalised and mainly on foreign markets. Other highly specialised sectors, on the other hand, such as non-metallic mineral products, are only slightly internationalised, the sectoral effect again predominating.

\subsubsection{Canada}

On the basis of the criteria adopted, Canada's industry is amongst the most internationalised of all the OECD countries (see previous chapter). It exports over $40 \%$ of its production, stocks of inward and outward direct investment stand at around 20\% of GDP and more than half of manufacturing output on the domestic market is under foreign control.

Specific to Canada, however, is that these results are to a large extent achieved with just one country -- the United States, and from this point of view Canadian industry is more regionalised than internationalised. Sectorally, the two most internationalised sectors are motor vehicles and scientific instruments, the former more particularly on the domestic market and the second almost equally on both. On foreign markets, the scientific instruments sector is more highly ranked because, despite its lower export ratio, it has a much lower concentration rate than does the motor vehicle industry (Annex Table 7), $98 \%$ of whose exports go to the American market, compared to $72 \%$ in the case of scientific instruments.

Chemicals/pharmaceuticals and non-electrical machinery are also among the more internationalised industries, while the sectors in which Canada is highly specialised -- i.e. non-ferrous metals and wood and paper -- are not broken down separately in the figures used. The plastics industry is less internationalised than in the majority of OECD countries. 
Figure 18. Classification of manufacturing sectors in Italy according to their degree of internationalisation

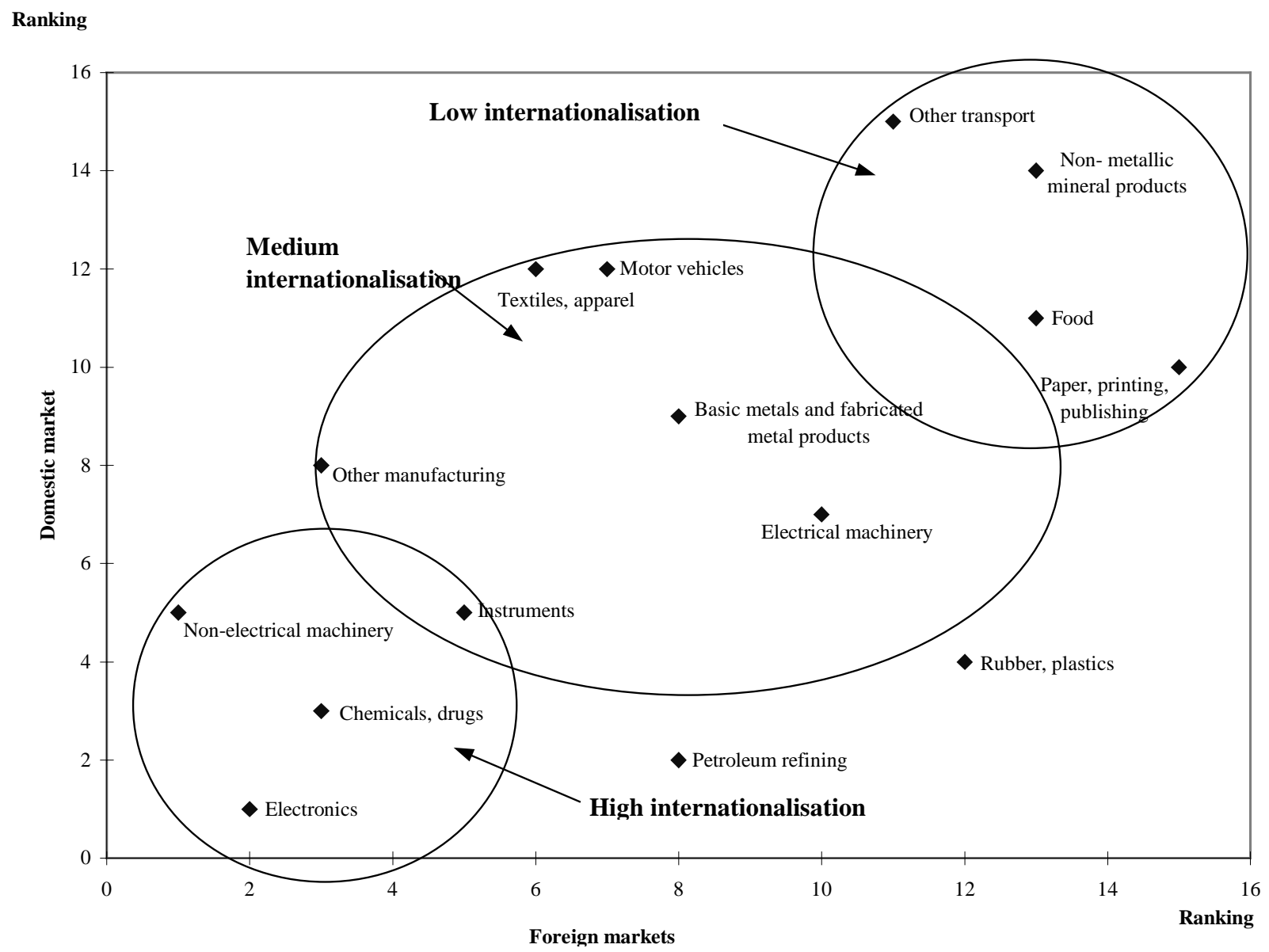

Source: OECD, AFA, Input-Output, and STAN databases (DSTI/EAS Division). 
DSTI/DOC(99)2

Figure 19. Classification of manufacturing sectors in Canada according to their degree of internationalisation

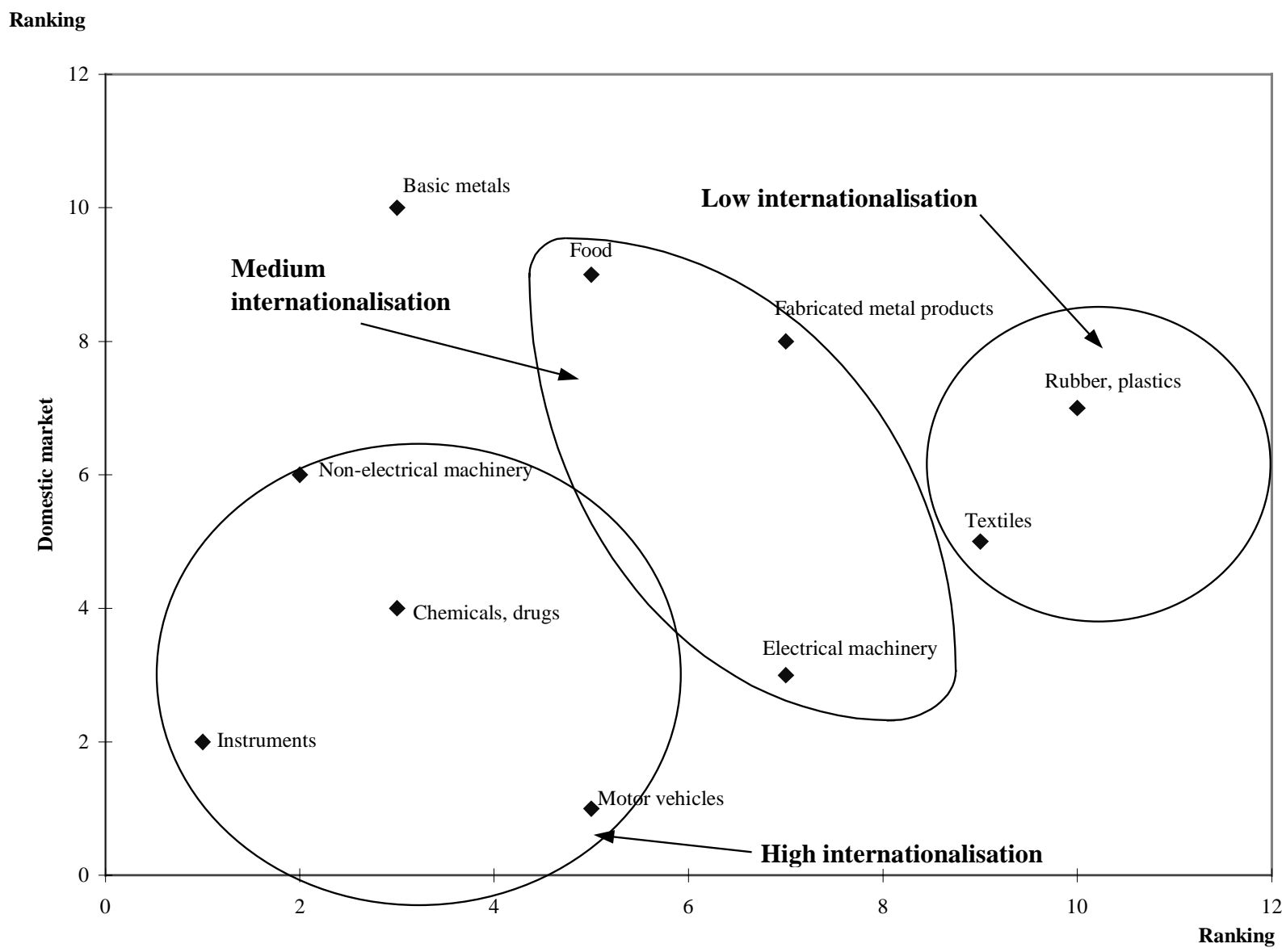

Foreign markets

Source: OECD, AFA, Input-Output and STAN databases (DSTI/EAS Division) and ISIS database (STD).

\subsubsection{Sweden}

Sweden's is one of the most internationalised industries, particularly on foreign markets. More than half of manufacturing output is exported, while stocks of outward direct investment account for more than 30\% of GDP. On the domestic market, on the other hand, the shares of production and manufacturing R\&D under foreign control are in the region of 18 and 14\% respectively, which are relatively low rates compared with those of other less internationalised countries. Sectorally, four industries are the most internationalised overall: electrical appliances, basic chemicals, precision instruments and non-electrical machinery. 
DSTI/DOC(99)2

Figure 20. Classification of manufacturing sectors in Sweden according to their degree of internationalisation

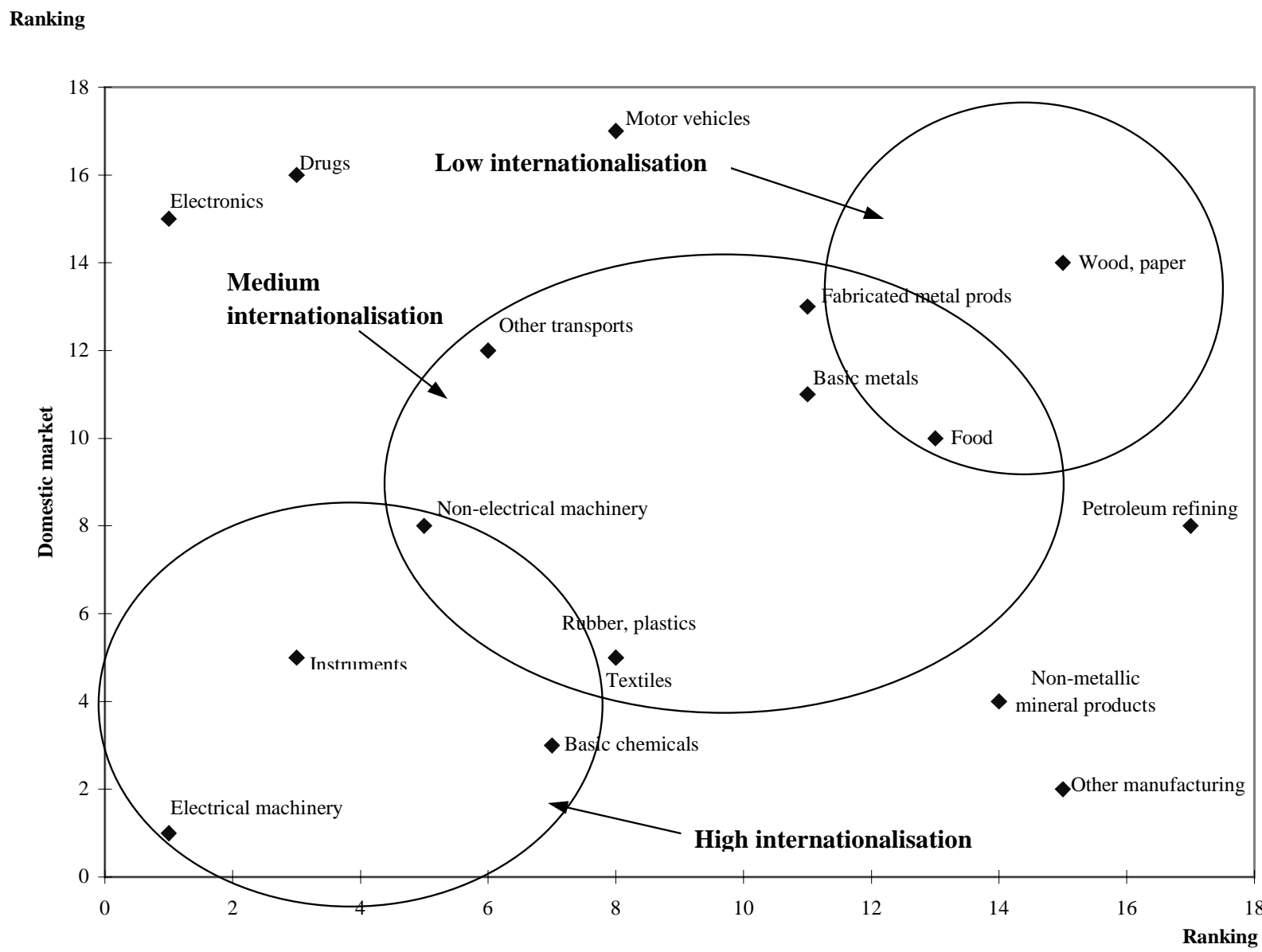

Foreign markets

Source: OECD, AFA, ANBERD and STAN databases (DSTI/EAS Division).

On foreign markets, the electronics industry (including telecommunications), in which Sweden is highly specialised, is as internationalised as the electrical appliances industry, but on the domestic market less than $5 \%$ of electronics production is under foreign control, compared with $65 \%$ of production of electrical appliances. In the motor vehicle industry, the disparities between internationalisation on foreign markets and on the domestic market are even more striking. More than $56 \%$ of motor vehicle production is exported, while on the domestic market barely $3.7 \%$ of production is foreign-controlled. Curiously, the wood and paper industry is less internationalised, despite Sweden being highly specialised in these sectors. Whereas on the domestic market there is no foreign investment and there are no imports of intermediate products, on foreign markets the industry's export ratio is lower than the manufacturing industry average (Annex Table 8). 


\subsubsection{Ireland}

Irish industry is notable for its very high level of internationalisation, particularly on the domestic market. Compared with certain small European countries whose industries are very internationalised, examples being the Netherlands, Sweden and Switzerland, whose multinationals are established in a great many countries, Ireland is more a host country for foreign investment and is very export-oriented. Unlike the countries just mentioned, on the other hand, it has no multinational firms of its own which could invest massively abroad. From this point of view, the internationalisation of Irish industry -- on foreign markets at least -- corresponds only to the first stage thereof, i.e. exports. Bearing these characteristics in mind, the most internationalised sectors are scientific instruments, computers, chemicals/pharmaceuticals, non-electrical machinery and other manufacturing industry.

Figure 21. Classification of manufacturing sectors in Ireland according to their degree of internationalisation

Ranking

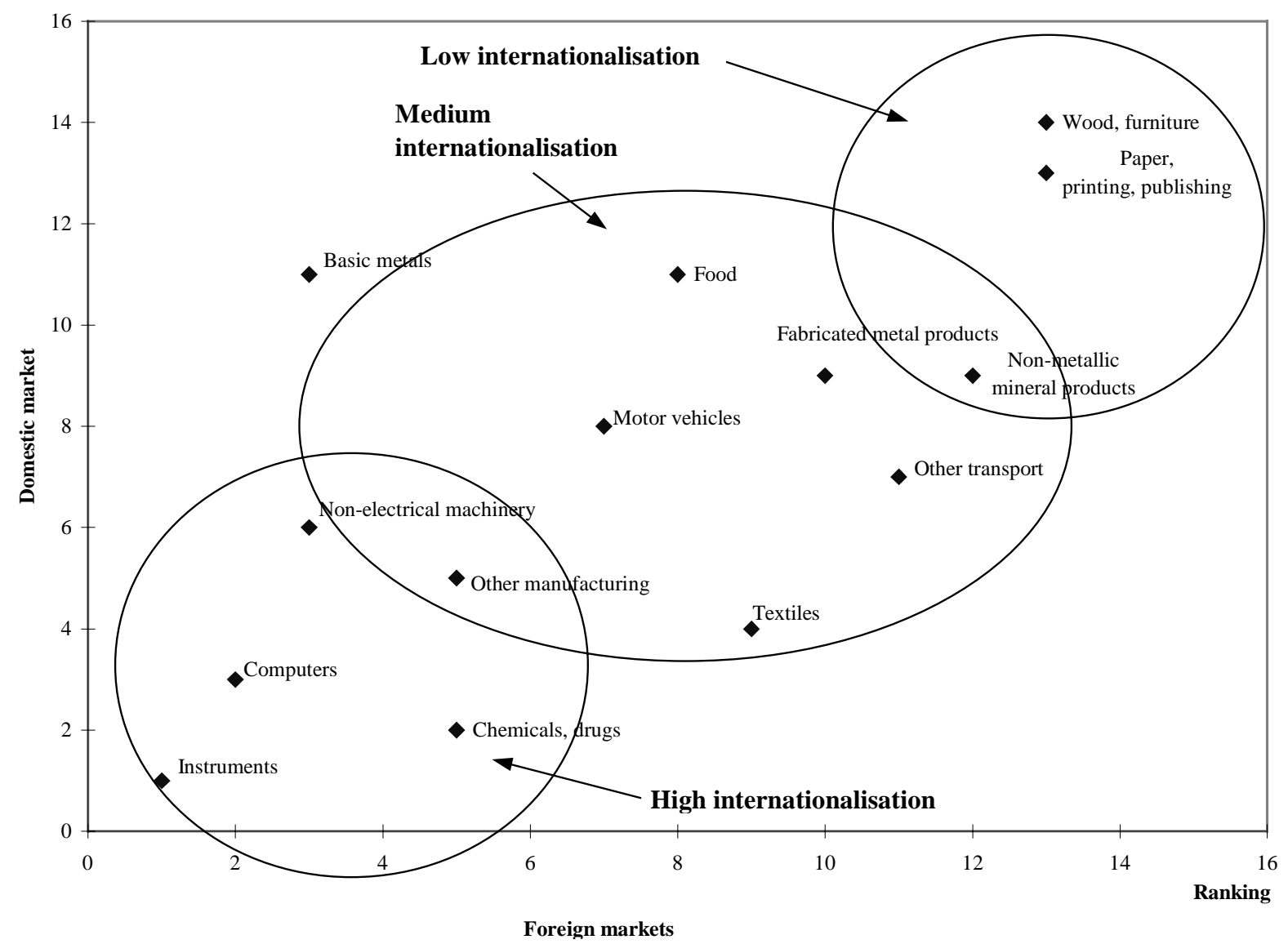

Source: OECD, AFA, Input-Output and BTD databases (DSTI/EAS Division) and ISIS database (STD). 
On the domestic market, more than $95 \%$ of the scientific instruments industry is foreign-controlled, while on foreign markets over $90 \%$ of output is exported, with the rate of geographical concentration low. The computer industry, which is dominated by American multinationals, exports virtually all of its production. The sectors which are among the least internationalised, both on the domestic and on foreign markets, include wood and furniture, paper, printing and publishing, where there is very little foreign presence. Generally speaking, the industries which export most are those that are under extensive foreign control.

\subsubsection{Finland}

Finland's industry is very industrialised from the trade standpoint, its exports recording one of the biggest increases between 1985 and 1994, with an improved geographical breakdown (Figures 4 and 5). It is, on the other hand, much less internationalised where direct investment and the decentralisation of $R \& D$ are concerned.

Figure 22. Classification of manufacturing sectors in Finland according to their degree of internationalisation

Ranking

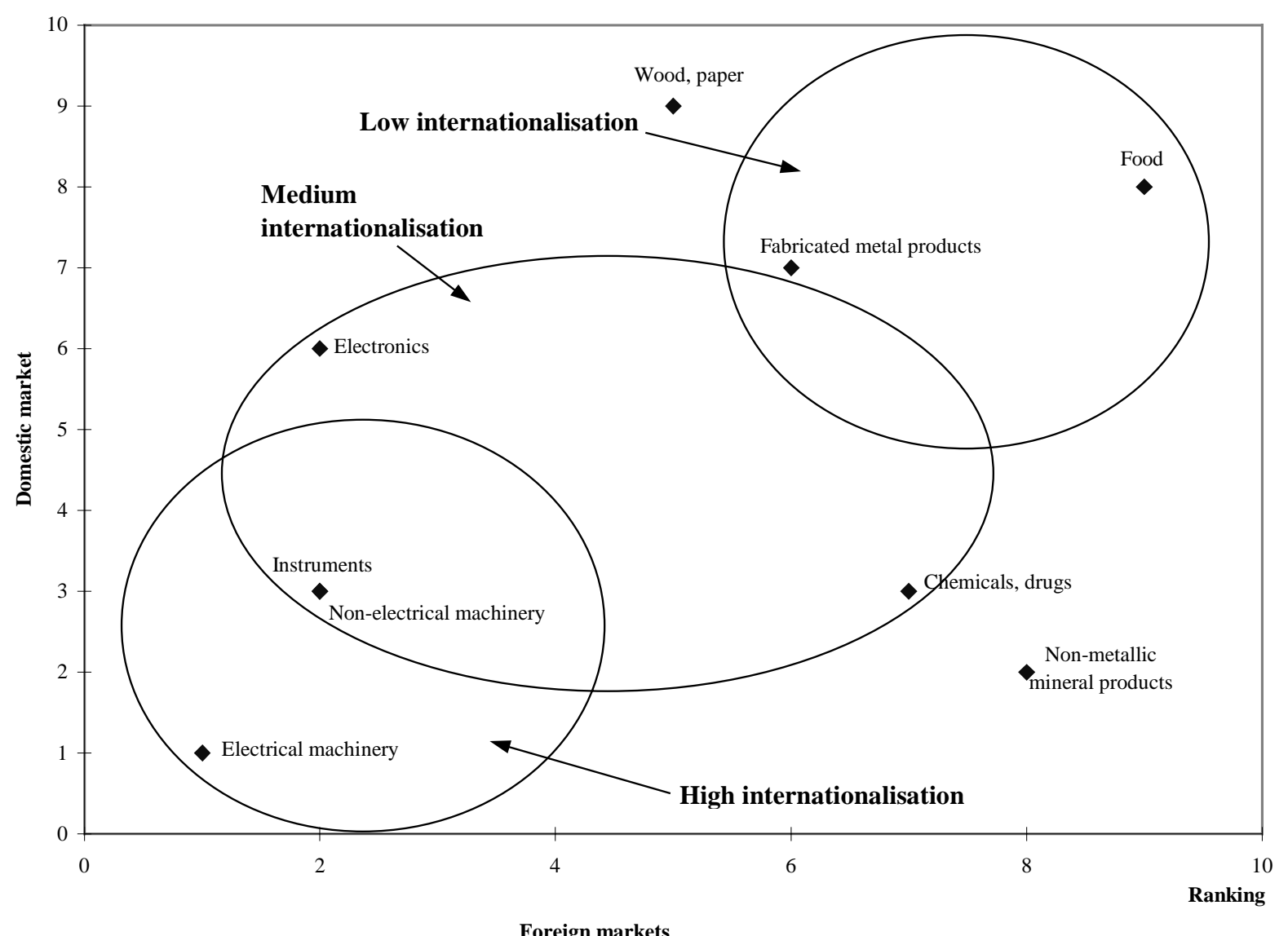

Source: OECD, AFA, Input-Output, ANBERD and STAN databases (DSTI/EAS Division). 
The data available show (Figure 22) that, sectorally, three industries are among the most internationalised: the electrical apparatus, non-electrical machinery and scientific instruments industries. The three industries are equally internationalised on the domestic and foreign markets. Two other industries which are very internationalised on the domestic market are the basic chemicals and mineral products industries. The wood and paper sectors, however, which have the biggest comparative advantages of all the OECD countries, are only very slightly internationalised, especially on the domestic market.

\section{Conclusions}

The object of the above analysis has been to identify each country's most internationalised and less internationalised industries on both foreign and domestic markets.

Three major difficulties were encountered. First, there was the lack of appropriate data in many countries, which restricted the possibilities of extending the findings to the whole of the OECD area. The second difficulty concerned the criteria and indicators used; the latter do not cover all the dimensions of the globalisation process, but they do take account of data availability. A third difficulty had to do with the sectoral breakdown, which differed according to the category of data, and sometimes the lack of data, particularly concerning international investment on foreign markets. Also, the lack of data over a longer period of time made it impossible to adopt a more dynamic approach to the level of globalisation of industry.

From the methodological standpoint, and in view of the objective -- i.e. to look for links between the level of globalisation of industrial sectors and their performance -- it would be better for the analysis to focus on each country's level of globalisation in a given sector rather than compare that level across different sectors in a particular country. However, this sort of approach would be even more difficult to adopt because the same indicators are not available for every country and therefore comparisons could well be distorted.

The first findings showed that, in general, manufacturing industry in small countries is much more internationalised than in the larger countries. Internationalisation is greater on foreign than on domestic markets, particularly in the case of small countries with a lot of multinational firms. From the sectoral standpoint, in the majority of countries the most internationalised industries are high and medium-technology industries (Annex Table 11), while low-technology sectors are the least internationalised. This is due to the fact that global demand for high-technology products is greater but that, by comparison with the costs involved in R\&D and innovation, it is still insufficient -- even in the case of the larger countries. The need to look for outside markets is confirmed by the sharp growth in trade and by the very high level of local production and geographical decentralisation of R\&D and innovation centres. The only exception to this general rule is the aerospace industry which according to the criteria used would seem to be the only moderately-internationalised high-tech industry, given the lack of production units abroad or transfers of R\&D laboratories. However, the overall classification of this sector would undoubtedly be different if other indicators currently not available, such as international subcontracting or co-operation agreements, were to be taken into account.

The degree of internationalisation of industry depends mainly on sectoral characteristics rather than on the specialisation of each country. Low-technology sectors, for example, are not very internationalised even when the countries in question are highly specialised. One of the most internationalised low-technology industries is the textiles/clothing industry. All these results will need to be reviewed in the light of further information on new countries and of new indicators which are not yet available. 


\section{ANNEX \\ Globalisation indicators of manufacturing industries}

Table 1: $\quad$ United States

Table 2: Japan

Table 3: Germany

Table 4: $\quad$ France

Table 5: United Kingdom

Table 6: $\quad$ Italy

Table 7: $\quad$ Canada

Table 8: $\quad$ Sweden

Table 9: $\quad$ Ireland

Table 10: Finland

Table 11: Classification of manufacturing industries according to their internationalisation level in each country (ranking) 
Annex Table 1. Globalisation indicators of manufacturing industries in the United States, 1995 or nearest year

\begin{tabular}{|c|c|c|c|c|c|c|c|c|c|c|c|c|}
\hline & \multicolumn{5}{|c|}{ Internal market } & \multicolumn{6}{|c|}{ External markets } & \multirow{2}{*}{$\begin{array}{r}\text { Global } \\
\text { rank }\end{array}$} \\
\hline & $\begin{array}{l}\text { Share of imports } \\
\text { of intermediate goods in } \\
\text { total interm. consumption }\end{array}$ & \begin{tabular}{c|} 
Share of \\
production under \\
foreign control
\end{tabular} & $\begin{array}{c}\text { Share of } \\
\text { R\&D under } \\
\text { foreign control }\end{array}$ & $\begin{array}{l}\text { Intra-firm } \\
\text { imports }{ }^{1}\end{array}$ & Rank & Export rate & $\begin{array}{c}\text { Export } \\
\text { concentration }^{2}\end{array}$ & $\begin{array}{c}\text { Direct } \\
\text { investment }\end{array}$ & $R \& D^{4}$ & $\begin{array}{l}\text { Intra-firm } \\
\text { exports }{ }^{5}\end{array}$ & Rank & \\
\hline Food & 4.13 & 8.97 & 19.22 & 10.17 & 13 & 7.22 & 9.54 & 27.33 & 25.48 & 18.90 & 8 & 11 \\
\hline Textiles & 10.54 & 6.92 & 14.48 & 0.75 & 14 & 11.02 & 6.97 & 5.12 & 9.49 & 2.42 & 14 & 16 \\
\hline Wood, furniture & 5.94 & 2.12 & 7.89 & 1.05 & 19 & 4.40 & 15.60 & 3.26 & 26.59 & 12.79 & 15 & 19 \\
\hline Paper, printing, publishing & 7.65 & 9.94 & 10.46 & 5.03 & 17 & 5.59 & 10.85 & 7.21 & 10.68 & 7.82 & 17 & 18 \\
\hline Basic chemicals, excl. drugs & 8.67 & 21.84 & 42.14 & 19.33 & 4 & 22.06 & 6.90 & 27.10 & 12.69 & 21.83 & 3 & 2 \\
\hline Drugs & 5.79 & 34.81 & 51.44 & 73.52 & 2 & 7.92 & 7.10 & 40.40 & 26.25 & 79.75 & 2 & 1 \\
\hline Petroleum refining & 26.55 & 13.49 & 13.52 & 59.29 & 2 & 4.46 & 6.96 & 97.17 & 0.17 & 2.94 & 13 & 6 \\
\hline Rubber and plastics & 8.10 & 16.01 & 19.66 & 18.12 & 6 & 5.81 & 18.39 & 20.83 & 19.42 & 20.15 & 10 & 10 \\
\hline Non-metallic mineral products & 5.61 & 27.29 & 35.49 & 11.27 & 7 & 6.12 & 16.18 & 11.13 & 8.71 & 13.35 & 15 & 12 \\
\hline Basic metals & 8.96 & 20.24 & 29.01 & 12.77 & 5 & 7.56 & 17.03 & 6.12 & 1.52 & 7.02 & 19 & 13 \\
\hline Fabricated metal products & 8.29 & 8.13 & 17.20 & 12.85 & 11 & 6.97 & 14.30 & 6.71 & 9.29 & 9.77 & 17 & 15 \\
\hline Non-electrical machinery, excl. computers & 9.12 & 10.39 & 10.65 & 12.14 & 8 & 22.70 & 7.12 & 11.62 & 12.36 & 14.30 & 9 & 8 \\
\hline Computers & 25.49 & 6.40 & 5.15 & 7.91 & 14 & 43.16 & 6.72 & 76.70 & 5.25 & 75.02 & 1 & 4 \\
\hline Electrical machinery & 9.62 & 25.52 & 27.12 & 20.48 & 1 & 24.37 & 13.28 & 16.65 & 38.41 & 16.22 & 5 & 3 \\
\hline Electronics & 16.07 & 8.58 & 11.96 & 7.92 & 8 & 27.74 & 6.10 & 19.50 & 4.59 & 27.80 & 4 & 5 \\
\hline Instruments & 10.62 & 13.00 & 5.69 & 4.50 & 12 & 17.66 & 7.02 & 23.35 & 5.29 & 35.23 & 6 & 9 \\
\hline Other manufacturing & 10.32 & 4.51 & 13.49 & 1.40 & 16 & 11.81 & 8.61 & 8.28 & 11.69 & 9.66 & 11 & 14 \\
\hline
\end{tabular}

1. Share of intra-firm imports of foreign affililiates in total imports.

2. Geographical concentration of exports: Herfindahl index.

3. Share of production of affililiates of national firms abroad in total national production.

4. Share of R\&D of affililiates of national firms abroad in total national R\&D.

5. Share of intra-firm exports of affililiates of national firms abroad in total national exports.

Source: OECD, AFA, Input-Output, ANBERD and STAN databases (DSTI/EAS Division). 
Annex Table 2. Globalisation indicators of manufacturing industries in Japan, 1995 or nearest year

\begin{tabular}{|c|c|c|c|c|c|c|c|c|}
\hline & \multicolumn{4}{|c|}{ Internal market } & \multicolumn{3}{|c|}{ External markets } & \multirow{2}{*}{$\begin{array}{c}\text { Global } \\
\text { rank }\end{array}$} \\
\hline & $\begin{array}{l}\text { Share of imports } \\
\text { of intermediate goods in } \\
\text { total interm. consumption }\end{array}$ & $\begin{array}{l}\text { Share of } \\
\text { production under } \\
\text { foreign control }\end{array}$ & $\begin{array}{c}\text { Share of } \\
\text { R\&D under } \\
\text { foreign control }\end{array}$ & Rank & Export rate & $\begin{array}{c}\text { Export } \\
\text { concentration }^{2}\end{array}$ & Rank & \\
\hline Food & 19.44 & 0.58 & 1.09 & 10 & 0.53 & 11.77 & 14 & 12 \\
\hline Textiles & 16.76 & 0.18 & 0.00 & 15 & 5.82 & 10.79 & 7 & 14 \\
\hline Wood, furniture & 21.82 & 0.46 & 0.05 & 13 & 0.58 & 16.03 & 15 & 15 \\
\hline Paper, printing, publishing & 23.48 & 0.13 & 0.00 & 13 & 1.24 & 10.13 & 10 & 13 \\
\hline Basic chemicals, excl. drugs & 27.98 & 8.41 & 3.57 & 2 & 22.18 & 8.56 & 1 & 1 \\
\hline Drugs & 27.03 & 21.90 & 8.02 & 1 & 3.34 & 11.91 & 11 & 3 \\
\hline Petroleum refining & 26.39 & 43.82 & 7.91 & 2 & 3.81 & 14.05 & 12 & 5 \\
\hline Rubber and plastics & 26.35 & 0.60 & 0.05 & 9 & 5.27 & 10.17 & 8 & 9 \\
\hline Non-metallic mineral products & 27.89 & 4.72 & 1.45 & 4 & 5.46 & 9.81 & 4 & 2 \\
\hline Basic metals & 27.99 & 0.01 & 0.00 & 10 & 6.85 & 8.67 & 3 & 8 \\
\hline Non-electrical machinery, excl. computers & 24.30 & 1.18 & 0.87 & 5 & 21.98 & 9.04 & 2 & 4 \\
\hline Transportation equipment & 22.34 & 0.58 & 0.09 & 12 & 23.37 & 16.44 & 9 & 11 \\
\hline Instruments & 21.12 & 7.85 & 0.99 & 6 & 62.50 & 13.79 & 5 & 6 \\
\hline Other manufacturing & 22.64 & 1.26 & 0.73 & 8 & 3.21 & 13.02 & 12 & 10 \\
\hline
\end{tabular}

1. Geographical concentration of exports: Herfindahl index.

Source: OECD, AFA, Input-Output, ANBERD and STAN databases (DSTI/EAS Division). 


\section{Annex Table 3. Globalisation indicators of manufacturing industries in Germany, 1994 or nearest year}

\begin{tabular}{|c|c|c|c|c|c|c|c|c|}
\hline & \multicolumn{3}{|c|}{ Internal market } & \multicolumn{4}{|c|}{ External markets } & \multirow{2}{*}{$\begin{array}{c}\text { Global } \\
\text { rank }\end{array}$} \\
\hline & $\begin{array}{l}\text { Share of imports } \\
\text { of intermediate goods in } \\
\text { total interm. consumption }\end{array}$ & \begin{tabular}{|c|} 
Share of \\
production under \\
foreign control
\end{tabular} & Rank & Export rate & $\begin{array}{c}\text { Export } \\
\text { concentration }^{1}\end{array}$ & $\begin{array}{c}\text { Direct } \\
\text { investment }^{2}\end{array}$ & Rank & \\
\hline Food & 16.87 & 12.01 & 9 & 12.44 & 8.08 & 2.08 & 15 & 15 \\
\hline Textiles & 23.78 & 2.78 & 11 & 44.91 & 5.18 & 6.50 & 6 & 7 \\
\hline Wood, paper & 21.16 & 3.92 & 11 & 18.58 & 7.79 & 2.25 & 14 & 14 \\
\hline Chemicals, drugs & 19.68 & 18.10 & 4 & 47.61 & 5.35 & 38.01 & 1 & 1 \\
\hline Petroleum refining & 69.49 & 37.57 & 1 & 5.71 & 7.59 & 0.18 & 16 & 11 \\
\hline Rubber, plastics & 21.33 & 6.83 & 7 & 17.94 & 6.97 & 12.01 & 10 & 9 \\
\hline Non-metallic mineral products & 12.50 & 5.40 & 15 & 11.63 & 6.58 & 6.31 & 13 & 16 \\
\hline Basic metals & 14.46 & 3.80 & 16 & 25.23 & 6.03 & 2.89 & 9 & 13 \\
\hline Fabricated metal products & 16.14 & 4.61 & 14 & 18.59 & 6.08 & 7.81 & 8 & 12 \\
\hline Non-electrical machinery, excl. computers & 12.75 & 8.28 & 13 & 42.63 & 4.37 & 9.10 & 5 & 8 \\
\hline Computers & 20.70 & 39.93 & 2 & 60.09 & 7.68 & 2.32 & 10 & 6 \\
\hline Motor vehicles & 16.92 & 20.49 & 5 & 45.49 & 6.65 & 18.71 & 6 & 4 \\
\hline Other transport & 23.98 & 11.16 & 3 & 76.59 & 22.74 & 1.97 & 12 & 9 \\
\hline Instruments & 17.13 & 14.22 & 6 & 92.95 & 5.27 & 9.85 & 1 & 2 \\
\hline Other manufacturing & 20.24 & 11.64 & 7 & 60.11 & 5.54 & 23.28 & 1 & 3 \\
\hline
\end{tabular}

1. Geographical concentration of exports: Herfindahl index.

2. Share of production of affililiates of national firms abroad in total national production.

Source: OECD, AFA, Input-Output and STAN databases (DSTI/EAS Division) 
DSTI/DOC(99)2

\section{Annex Table 4. Globalisation indicators of manufacturing industries in France, 1995 or nearest year}

\begin{tabular}{|c|c|c|c|c|c|c|c|c|}
\hline & \multicolumn{4}{|c|}{ Internal market } & \multicolumn{3}{|c|}{ External markets } & \multirow{2}{*}{$\begin{array}{r}\text { Globa } \\
\text { rank }\end{array}$} \\
\hline & $\begin{array}{l}\text { Share of imports } \\
\text { of intermediate goods in } \\
\text { total interm. consumption }\end{array}$ & $\begin{array}{l}\text { Share of } \\
\text { production under } \\
\text { foreign control }\end{array}$ & $\begin{array}{c}\text { Share of } \\
\text { R\&D under } \\
\text { foreign control }\end{array}$ & Rank & Export rate & $\begin{array}{c}\text { Export } \\
\text { concentration }^{1}\end{array}$ & Rank & \\
\hline Textiles & 29.06 & 14.62 & 9.16 & 10 & 34.80 & 6.68 & 6 & 8 \\
\hline Wood, furniture & 17.77 & 22.12 & 7.59 & 13 & 13.24 & 10.40 & 16 & 16 \\
\hline Basic chemicals, excl. drugs & 30.02 & 50.32 & 17.04 & 3 & 55.16 & 7.29 & 3 & 2 \\
\hline Drugs & 20.49 & 62.78 & 47.81 & 2 & 26.85 & 4.50 & 5 & 3 \\
\hline Rubber, plastics & 45.01 & 31.57 & 10.85 & 5 & 23.05 & 10.91 & 15 & 8 \\
\hline Non-metallic mineral products & 6.90 & 28.73 & 16.68 & 11 & 19.33 & 8.67 & 14 & 14 \\
\hline Basic metals & 31.11 & 19.30 & 5.63 & 8 & 32.58 & 9.85 & 12 & 10 \\
\hline Fabricated metal products & 20.30 & 14.08 & 7.36 & 16 & 19.47 & 7.54 & 13 & 15 \\
\hline Non-electrical machinery, excl. computers & 21.49 & 45.29 & 21.44 & 4 & 35.97 & 5.83 & 2 & 3 \\
\hline Computers & 34.45 & 74.47 & 37.92 & 1 & 42.49 & 9.07 & 7 & 1 \\
\hline Electrical machinery & 20.82 & 35.21 & 19.39 & 6 & 42.17 & 6.29 & 4 & 5 \\
\hline Motor vehicles & 19.87 & 18.35 & 8.82 & 12 & 44.21 & 10.27 & 9 & 11 \\
\hline Aircraft & 29.22 & 12.78 & 1.16 & 13 & 57.43 & 12.57 & 10 & 12 \\
\hline Instruments & 19.20 & 31.37 & 13.66 & 8 & 74.26 & 6.13 & 1 & 6 \\
\hline Other manufacturing & 13.21 & 19.29 & 10.34 & 13 & 29.91 & 7.71 & 11 & 13 \\
\hline
\end{tabular}

1. Geographical concentration of exports: Herfindahl index.

Source: OECD, AFA, Input-Output, ANBERD and STAN databases (DSTI/EAS Division). 
Annex Table 5. Globalisation indicators of manufacturing industries in the United Kingdom, 1995 or nearest year

\begin{tabular}{|c|c|c|c|c|c|c|c|c|}
\hline & \multicolumn{4}{|c|}{ Internal market } & \multicolumn{3}{|c|}{ External markets } & \multirow{2}{*}{$\begin{array}{c}\text { Global } \\
\text { rank }\end{array}$} \\
\hline & $\begin{array}{l}\text { Share of imports } \\
\text { of intermediate goods in } \\
\text { total interm. consumption }\end{array}$ & $\begin{array}{c}\text { Share of } \\
\text { production under } \\
\text { foreign control }\end{array}$ & $\begin{array}{l}\text { Share of } \\
\text { R\&D under } \\
\text { foreign control }\end{array}$ & Rank & Export rate & $\begin{array}{c}\text { Export } \\
\text { concentration }^{1}\end{array}$ & Rank & \\
\hline Food & 13.16 & 16.29 & 33.72 & 16 & 13.21 & 6.32 & 16 & 15 \\
\hline Wood, furniture & 26.10 & 3.97 & 31.25 & 17 & 6.00 & 8.34 & 17 & 18 \\
\hline Paper, printing, publishing & 29.33 & 19.13 & 58.62 & 7 & 11.47 & 6.12 & 12 & 9 \\
\hline Chemicals, drugs & 28.47 & 35.72 & 30.72 & 9 & 47.08 & 5.69 & 1 & 5 \\
\hline Petroleum refining & 13.45 & 60.53 & 22.95 & 14 & 13.93 & 15.50 & 17 & 16 \\
\hline Rubber, plastics & 33.75 & 22.21 & 59.32 & 3 & 20.89 & 7.45 & 12 & 5 \\
\hline Non-metallic mineral products & 17.74 & 9.90 & 16.67 & 18 & 14.87 & 6.29 & 11 & 17 \\
\hline Basic metals & 29.72 & 23.19 & 25.76 & 10 & 41.69 & 6.31 & 7 & 10 \\
\hline Fabricated metal products & 24.01 & 15.46 & 46.00 & 13 & 16.89 & 4.86 & 5 & 14 \\
\hline Non-electrical machinery, excl. computers & 25.87 & 24.59 & 30.95 & 12 & 40.70 & 5.51 & 2 & 8 \\
\hline Electrical machinery & 29.17 & 17.42 & 30.57 & 14 & 40.14 & 5.57 & 4 & 13 \\
\hline Electronics & 33.19 & 31.71 & 33.73 & 4 & 74.69 & 8.05 & 5 & 3 \\
\hline Motor vehicles & 29.39 & 60.98 & 80.00 & 2 & 39.12 & 8.25 & 12 & 3 \\
\hline Other transport & 42.91 & 13.14 & 44.89 & 8 & 45.47 & 15.87 & 15 & 12 \\
\hline Instruments & 27.23 & 48.91 & 52.48 & 5 & 69.48 & 6.30 & 3 & 2 \\
\hline Other manufacturing & 31.49 & 17.93 & 57.14 & 5 & 64.75 & 10.65 & 10 & 7 \\
\hline
\end{tabular}

1. Geographical concentration of exports: Herfindahl index.

Source: OECD, AFA, Input-Output and STAN databases (DSTI/EAS Division). 


\section{Annex Table 6. Globalisation indicators of manufacturing industries in Italy, 1994 or nearest year}

DSTI/DOC(99)2

\begin{tabular}{|c|c|c|c|c|c|c|c|c|}
\hline & \multicolumn{4}{|c|}{ Internal market } & \multicolumn{3}{|c|}{ External markets } & \multirow{2}{*}{$\begin{array}{c}\text { Global } \\
\text { rank }\end{array}$} \\
\hline & $\begin{array}{l}\text { Share of imports } \\
\text { of intermediate goods in } \\
\text { total interm. consumption }\end{array}$ & \begin{tabular}{|c|} 
Share of \\
production under \\
foreign control
\end{tabular} & $\begin{array}{c}\text { Share of } \\
\text { R\&D under } \\
\text { foreign control }\end{array}$ & Rank & Export rate & $\begin{array}{c}\text { Export } \\
\text { concentration }\end{array}$ & Rank & \\
\hline Food & 19.32 & 17.56 & 2.60 & 11 & 12.04 & 9.97 & 13 & 12 \\
\hline Textiles & 23.77 & 2.77 & 5.17 & 12 & 36.50 & 8.86 & 6 & 10 \\
\hline Paper, printing, publishing & 19.19 & 11.57 & 6.78 & 10 & 10.65 & 11.16 & 15 & 14 \\
\hline Chemicals, drugs & 25.56 & 63.85 & 35.71 & 3 & 31.34 & 6.59 & 3 & 2 \\
\hline Petroleum refining & 86.56 & 36.39 & 18.49 & 2 & 16.50 & 4.47 & 8 & 3 \\
\hline Rubber, plastics & 30.36 & 19.18 & 12.42 & 4 & 24.99 & 10.22 & 12 & 7 \\
\hline Non-metallic mineral products & 14.73 & 8.84 & 11.50 & 14 & 20.51 & 10.28 & 13 & 15 \\
\hline Basic metals and fabricated metal products & 24.17 & 6.66 & 5.59 & 9 & 28.27 & 7.99 & 8 & 9 \\
\hline Non-electrical machinery, excl. computers & 18.95 & 33.19 & 13.46 & 5 & 49.23 & 4.23 & 1 & 4 \\
\hline Electrical machinery & 15.35 & 29.28 & 12.18 & 7 & 27.87 & 8.60 & 10 & 8 \\
\hline Electronics & 31.61 & 90.58 & 68.22 & 1 & 42.99 & 7.53 & 2 & 1 \\
\hline Other transport & 23.33 & 0.32 & 2.90 & 15 & 32.20 & 14.50 & 11 & 13 \\
\hline Instruments & 23.55 & 9.46 & 14.06 & 5 & 29.60 & 6.85 & 5 & 5 \\
\hline Other manufacturing & 36.93 & 9.13 & 0.29 & 8 & 74.98 & 9.80 & 3 & 6 \\
\hline
\end{tabular}

1. Geographical concentration of exports: Herfindahl index.

Source: OECD, AFA, Input-Output and STAN databases (DSTI/EAS Division). 
Annex Table 7. Globalisation indicators of manufacturing industries in Canada, 1994 or nearest year

\begin{tabular}{|c|c|c|c|c|c|c|c|c|}
\hline & \multicolumn{4}{|c|}{ Internal market } & \multicolumn{3}{|c|}{ External markets } & \multirow{2}{*}{$\begin{array}{c}\text { Global } \\
\text { rank }\end{array}$} \\
\hline & $\begin{array}{l}\text { Share of imports } \\
\text { of intermediate goods in } \\
\text { total interm. consumption }\end{array}$ & $\begin{array}{l}\text { Share of } \\
\text { production under } \\
\text { foreign control }\end{array}$ & $\begin{array}{l}\text { Share of } \\
\text { R\&D under } \\
\text { foreign control }\end{array}$ & Rank & Export rate & $\begin{array}{c}\text { Export } \\
\text { concentration }\end{array}$ & Rank & \\
\hline Food & 8.24 & 34.93 & 55.84 & 9 & 15.57 & 51.34 & 5 & 7 \\
\hline Textiles & 30.52 & 30.86 & 83.67 & 5 & 17.73 & 71.12 & 9 & 6 \\
\hline Chemicals, drugs & 20.05 & 52.98 & 84.44 & 4 & 48.75 & 61.59 & 3 & 3 \\
\hline Rubber, plastics & 28.30 & 35.78 & 27.78 & 7 & 28.06 & 90.53 & 10 & 9 \\
\hline Basic metals & 21.52 & 7.99 & 1.14 & 10 & 46.26 & 59.42 & 3 & 10 \\
\hline Fabricated metal products & 23.63 & 45.96 & 21.88 & 8 & 33.70 & 74.00 & 7 & 8 \\
\hline Non-electrical machinery & 41.53 & 36.62 & 15.50 & 6 & 61.43 & 69.41 & 2 & 4 \\
\hline Electrical machinery & 25.72 & 85.44 & 53.45 & 3 & 45.86 & 76.04 & 7 & 5 \\
\hline Motor vehicles & 53.99 & 90.93 & 87.61 & 1 & 74.00 & 96.95 & 5 & 1 \\
\hline Instruments & 37.01 & 93.34 & 24.24 & 2 & 55.12 & 51.80 & 1 & 2 \\
\hline
\end{tabular}

1. Geographical concentration of exports: Herfindahl index.

Source: OECD, AFA, Input-Output and STAN databases (DSTI/EAS Division) and ISIS database (STD). 
Annex Table 8. Globalisation indicators of manufacturing industries in Sweden, 1994 or nearest year

DSTI/DOC(99)2

\begin{tabular}{|c|c|c|c|c|c|c|c|}
\hline & \multicolumn{3}{|c|}{ Internal market } & \multicolumn{3}{|c|}{ External markets } & \multirow{2}{*}{$\begin{array}{c}\text { Global } \\
\text { rank }\end{array}$} \\
\hline & $\begin{array}{c}\text { Share of } \\
\text { production under } \\
\text { foreign control }\end{array}$ & $\begin{array}{l}\text { Share of } \\
\text { R\&D under } \\
\text { foreign control }\end{array}$ & Rank & Export rate & $\begin{array}{c}\text { Export } \\
\text { concentration }^{1}\end{array}$ & Rank & \\
\hline Food & 18.25 & 13.65 & 10 & 8.90 & 8.23 & 13 & 13 \\
\hline Textiles & 21.00 & 41.81 & 5 & 66.73 & 9.43 & 8 & 7 \\
\hline Wood, paper & 6.18 & 1.60 & 14 & 45.59 & 9.91 & 15 & 17 \\
\hline Basic chemicals, excl. drugs & 61.12 & 48.62 & 3 & 58.58 & 7.15 & 7 & 2 \\
\hline Drugs & 4.25 & 0.96 & 16 & 73.45 & 7.27 & 3 & 11 \\
\hline Petroleum refining & 7.61 & 65.25 & 8 & 42.61 & 11.63 & 17 & 13 \\
\hline Rubber, plastics & 34.31 & 39.97 & 5 & 60.76 & 8.66 & 8 & 7 \\
\hline Non-metallic mineral products & 41.13 & 35.46 & 4 & 25.61 & 8.60 & 14 & 10 \\
\hline Basic metals & 17.75 & 11.78 & 11 & 57.47 & 8.61 & 11 & 12 \\
\hline Fabricated metal products & 6.83 & 4.20 & 13 & 30.54 & 7.45 & 11 & 15 \\
\hline Non-electrical machinery, excl. computers & 36.53 & 29.50 & 8 & 63.71 & 5.57 & 5 & 4 \\
\hline Electrical machinery & 64.61 & 72.40 & 1 & 98.32 & 5.28 & 1 & 1 \\
\hline Electronics & 4.39 & 1.30 & 15 & 74.19 & 5.02 & 1 & 6 \\
\hline Motor vehicles & 3.65 & 0.60 & 17 & 56.39 & 8.27 & 8 & 16 \\
\hline Other transport & 15.52 & 4.65 & 12 & 71.22 & 8.16 & 6 & 9 \\
\hline Instruments & 40.01 & 32.86 & 5 & 70.28 & 6.27 & 3 & 3 \\
\hline Other manufacturing & 44.33 & 87.98 & 2 & 30.87 & 8.92 & 15 & 5 \\
\hline
\end{tabular}

1. Geographical concentration of exports: Herfindahl index.

Source: OECD, AFA, ANBERD and STAN databases (DSTI/EAS Division). 
DSTI/DOC(99)2

Annex:Table 9. Globalisation indicators of manufacturing industries in Ireland, 1995 or nearest year

\begin{tabular}{|c|c|c|c|c|c|c|c|}
\hline & \multicolumn{3}{|c|}{ Internal market } & \multicolumn{3}{|c|}{ External markets } & \multirow{2}{*}{$\begin{array}{c}\text { Global } \\
\text { rank }\end{array}$} \\
\hline & $\begin{array}{l}\text { Share of } \\
\text { production under } \\
\text { foreign control }\end{array}$ & $\begin{array}{l}\text { Share of } \\
\text { R\&D under } \\
\text { foreign control }\end{array}$ & Rank & Export rate & $\begin{array}{c}\text { Export } \\
\text { concentration }{ }^{1}\end{array}$ & Rank & \\
\hline Food & 32.59 & 25.08 & 11 & 52.64 & 16.34 & 8 & 11 \\
\hline Textiles & 50.73 & 73.06 & 4 & 77.71 & 32.58 & 9 & 6 \\
\hline Wood, furniture & 16.62 & 13.59 & 14 & 20.06 & 59.75 & 13 & 14 \\
\hline Paper, printing, publishing & 18.22 & 24.76 & 13 & 8.12 & 41.35 & 13 & 13 \\
\hline Chemicals, drugs & 73.28 & 89.19 & 2 & 91.72 & 28.65 & 5 & 3 \\
\hline Non-metallic mineral products & 49.38 & 26.75 & 9 & 24.91 & 22.65 & 12 & 12 \\
\hline Basic metals & 10.58 & 49.86 & 11 & 90.90 & 14.91 & 3 & 8 \\
\hline Fabricated metal products & 37.61 & 28.15 & 9 & 46.41 & 22.26 & 10 & 10 \\
\hline Non-electrical machinery, excl. computers & 65.59 & 32.72 & 6 & 69.11 & 11.59 & 3 & 4 \\
\hline Computers & 88.50 & 60.52 & 3 & 97.37 & 12.49 & 2 & 2 \\
\hline Motor vehicles & 13.25 & 88.15 & 8 & 41.75 & 11.88 & 7 & 7 \\
\hline Other transport & 29.08 & 63.42 & 7 & 70.27 & 37.94 & 11 & 9 \\
\hline Instruments & 96.51 & 88.50 & 1 & 91.94 & 8.07 & 1 & 1 \\
\hline Other manufacturing & 77.63 & 31.40 & 5 & 32.37 & 9.85 & 5 & 5 \\
\hline
\end{tabular}

1. Geographical concentration of exports: Herfindahl index.

Source: OECD, AFA, and BTD databases (DSTI/EAS Division) and ISIS database (STD). 
Annex Table 10. Globalisation indicators of manufacturing industries in Finland, 1995 or nearest year

\begin{tabular}{|c|c|c|c|c|c|c|c|}
\hline & \multicolumn{3}{|c|}{ Internal market } & \multicolumn{3}{|c|}{ External markets } & \multirow{2}{*}{$\begin{array}{c}\text { Global } \\
\text { rank }\end{array}$} \\
\hline & $\begin{array}{c}\text { Share of } \\
\text { production under } \\
\text { foreign control }\end{array}$ & $\begin{array}{c}\text { Share of } \\
\text { R\&D under } \\
\text { foreign control }\end{array}$ & Rank & Export rate & $\begin{array}{c}\text { Export } \\
\text { concentration }^{1}\end{array}$ & Rank & \\
\hline Food & 6.67 & 4.62 & 8 & 8.14 & 12.47 & 9 & 9 \\
\hline Wood, paper & 2.16 & 0.74 & 9 & 49.95 & 7.92 & 5 & 7 \\
\hline Chemicals, drugs & 18.24 & 5.61 & 3 & 43.28 & 10.28 & 7 & 6 \\
\hline Non-metallic mineral products & 29.13 & 29.11 & 2 & 24.79 & 10.28 & 8 & 4 \\
\hline Fabricated metal products & 11.55 & 2.38 & 7 & 30.64 & 8.53 & 6 & 7 \\
\hline Non-electrical machinery & 13.11 & 7.63 & 3 & 49.44 & 4.91 & 2 & 2 \\
\hline Electrical machinery & 50.89 & 69.17 & 1 & 77.95 & 4.94 & 1 & 1 \\
\hline Electronics & 7.46 & 5.59 & 6 & 69.68 & 5.81 & 2 & 4 \\
\hline Instruments & 13.62 & 5.99 & 3 & 51.69 & 5.57 & 2 & 2 \\
\hline
\end{tabular}

1. Geographical concentration of exports: Herfindahl index.

Source: OECD, AFA and STAN databases. (DSTI/EAS Division). 
DSTI/DOC(99)2

Annex Table 11. Classification of manufacturing industries according to their internationalisation level in each country (ranking)

\begin{tabular}{|c|c|c|c|c|c|c|c|c|c|c|c|}
\hline \multicolumn{12}{|l|}{ Industries } \\
\hline & USA & JAP & GER & FRA & UK & ITA & CAN & SWE & IRL & FIN & $\begin{array}{l}\text { Global } \\
\text { rank }\end{array}$ \\
\hline Food & 11 & 12 & 15 & .. & 15 & 12 & 7 & 13 & 11 & 9 & 15 \\
\hline Textile-apparel & 16 & 14 & 7 & 8 & 10 & 10 & 6 & 7 & 6 & .. & 11 \\
\hline Wood, furniture & 19 & 15 & 14 & 16 & 18 &.. & .. & 17 & 14 & ) 7 & 16 \\
\hline Paper, printing & 18 & 13 & .. & .. & 9 & ) & .. &.. & 13 & ) & 17 \\
\hline Basic chemicals & 2 & 1 & 1 & 2 & 5 & 2 & ) 3 & 2 & ) 3 & 6 & $1=$ \\
\hline Drugs & 1 & 3 & .. & 3 &.. & ) & ) & 11 & ) & ) & 3 \\
\hline Petroleum refining & 6 & 5 & 11 & .. & 16 & 3 & .. & 13 & .. & .. & 10 \\
\hline Rubber, plastics & 10 & 9 & 9 & 8 & 5 & 7 & 9 & 7 & .. & .. & 9 \\
\hline Non-metallic mineral products & 12 & 2 & 16 & 14 & 17 & 15 & .. & 10 & 12 & 4 & 13 \\
\hline Basic metals & 13 & 8 & 13 & 10 & 10 & ) & 10 & 12 & 8 & .. & 12 \\
\hline Fabricated metal products & 15 & .. & 12 & 15 & 14 & ) 9 & 8 & 15 & 10 & 7 & 16 \\
\hline Non-electrical machinery & 8 & 4 & 8 & 3 & 8 & 4 & 4 & 4 & 4 & 2 & 5 \\
\hline Computers & 4 &.. & 6 & 1 & 1 & .. & .. & .. & 2 & .. & $1=$ \\
\hline Electrical machinery & 3 & 6 & ) 5 & 5 & 13 & 8 & 5 & 1 & .. & 1 & 6 \\
\hline Electronic equipment & 5 & ) & ) & 7 & 3 & 1 & .. & 6 & .. & 4 & 3 \\
\hline Other transport equipment & 17 & 11 & 9 & 12 & 12 & 13 & .. & 9 & 9 & .. & 14 \\
\hline Motor vehicles & 6 & .. & 4 & 11 & 3 & 11 & 1 & 16 & 7 & .. & 7 \\
\hline Instruments & 9 & 6 & 2 & 6 & 2 & 5 & 2 & 3 & 1 & 2 & 2 \\
\hline Other manufacturing & 14 & 10 & 3 & 13 & 7 & 6 & .. & 5 & 5 & .. & 8 \\
\hline
\end{tabular}


DSTI/DOC(99)2

\section{NOTES}

1 A detailed bibliography of these studies may be found in OECD (1998), Open Markets Matter: The Benefits of Trade and Investment Liberalisation, OECD, 1998.

RICHARDSON, J.D. et al. (1988) "US-Performance and Trade Strategy in a Shifting Global Economy" in Feketekuty, G. and B. Stockes, Ed. Trade Strategies for a New Area: Ensuring U.S. Leadership into Global Economy, pp. 39-64. Council on Foreign Relations and the Monetary Institute of International Studies, New York.

OECD (1994), The Performance of Foreign Affiliates in OECD Countries, Paris.

Many of the features of globalisation are also described in Globalisation of Industry: Overview and Sector Reports, OECD, 1996.

A. Wyckoff (1993), "The Extension of Networks of Production across Borders", OECD, STI Review No. 13.

For want of the appropriate data, it was possible to quantify only the last three characteristics -- and for a small number of countries.

An establishment is made up of a set of entities which are controlled by a single centre or which belong to one owner, and whose activity is determined by the main activity of all the component units or workshops. It has no legal autonomy, while its accounts include all the information about production and intermediate consumption, but exclude other variables such as overheads, R\&D and the gross operating surplus which are booked in the firm's accounts.

A firm, or enterprise, is a legal entity with the right to conduct its activities under its own name. It may be made up of several establishments.

A group of enterprises consists of a number of firms whose activities may have to do with either industry or services. When referring to a sector, it is therefore important to say what its component entities are. Depending on whether it is made up of establishments or firms, the production and employment figures and the figures for other variables will differ. Given what has just been said, when relating a sector's performance to its degree of globalisation, two major difficulties can arise according to whether the sector is defined on the basis of establishments or of firms. If the reference unit is an establishment, production and employment figures will probably be more accurately measured than at firm level.

10 R. Gordon (1996): "Globalisation, New Production Systems and the Spatial Division of Labor" in W. Liffek and A. Charles (eds.)., The New Division of Labour: Emerging Forms of Work Organisation in International Perspective Berlin, Walter de Gruyer. 
12 OECD (1998), "Internationalisation of Industrial R\&D: Patterns and Trends", report prepared for the OECD.

13 This section covers countries which have sectoral data in at least two of the three categories taken into account, namely trade, investment and foreign-controlled R\&D. Some of the countries which do have such data have not been included because of problems of comparability between data on foreign firms and national firms (e.g. Mexico).

14 S. Bécuwe and C. Mathieu (1988), in Industrie Française et Mondialisation, published by the Secretariat of State for Industry.

15 For a broader discussion of the indicators concerning intra-branch and intra-firm trade, see the previous section.

15 Ibid.

16 Indicated between brackets is the sector of activity in the ISIC Rev. 2 classification used in this study. 